Prepared in cooperation with the Lewis County Public Utility District, Washington

\title{
Passage Survival of Juvenile Steelhead, Coho Salmon, and Chinook Salmon in Lake Scanewa and at Cowlitz Falls Dam, Cowlitz River, Washington, 2010-16
}

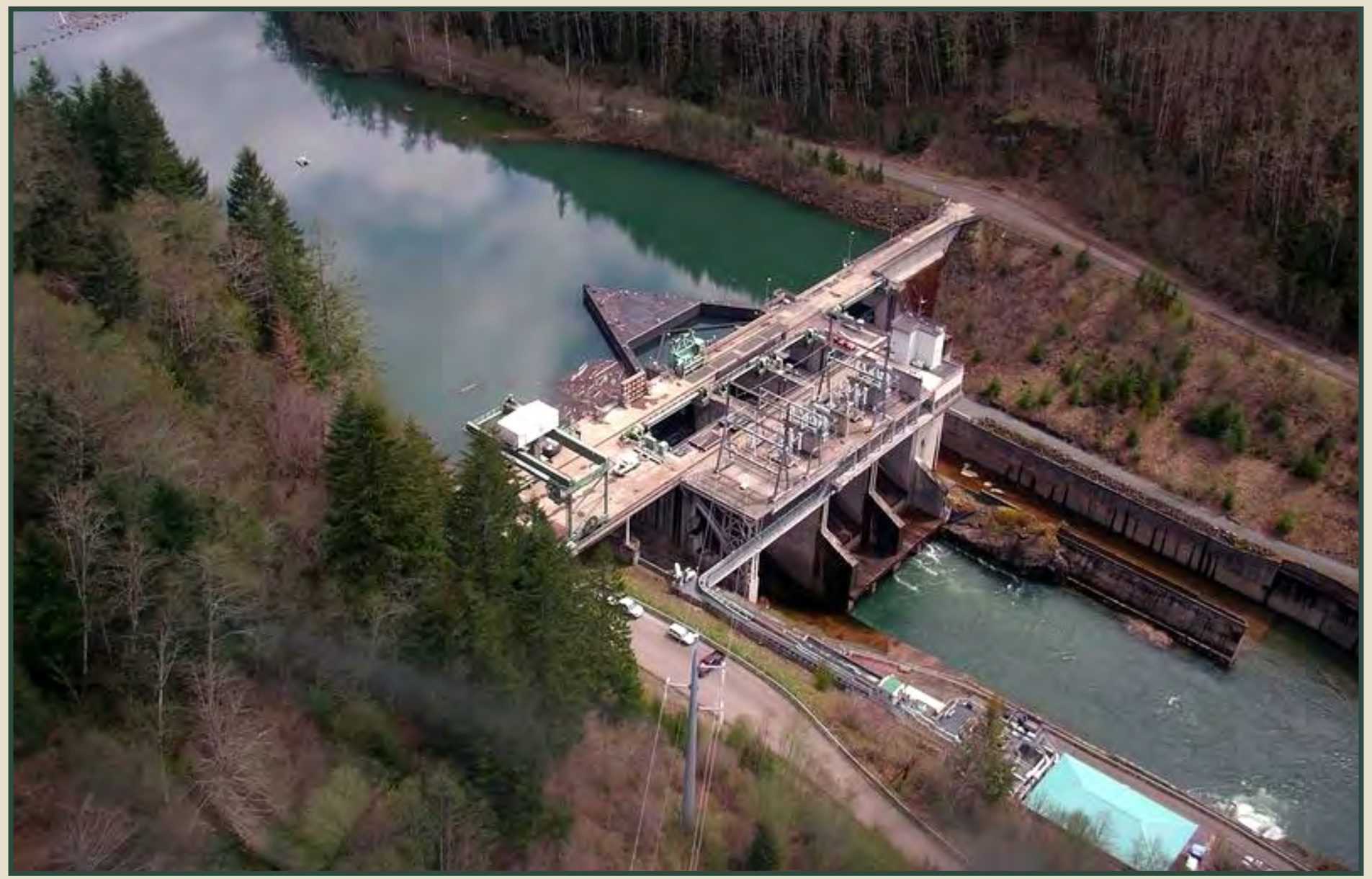

Open-File Report 2018-1050 
Cover: Aerial view of Cowlitz Falls Dam in Randal, Washington. Photograph by John Serl, Washington Department of Fish and Wildlife, 2010. 


\section{Passage Survival of Juvenile Steelhead, Coho Salmon, and Chinook Salmon in Lake Scanewa and at Cowlitz Falls Dam, Cowlitz River, Washington, 2010-16}

By Theresa L. Liedtke, Tobias J. Kock, and William Hurst

Prepared in cooperation with the Lewis County Public Utility District, Washington

Open-File Report 2018-1050

U.S. Department of the Interior

U.S. Geological Survey 


\section{U.S. Department of the Interior \\ RYAN K. ZINKE, Secretary}

\section{U.S. Geological Survey \\ William H. Werkheiser, Deputy Director \\ exercising the authority of the Director}

U.S. Geological Survey, Reston, Virginia: 2018

For more information on the USGS-the Federal source for science about the Earth, its natural and living resources, natural hazards, and the environment-visit https://www.usgs.gov/ or call 1-888-ASK-USGS.

For an overview of USGS information products, including maps, imagery, and publications, visit https:/store.usgs.gov.

Any use of trade, firm, or product names is for descriptive purposes only and does not imply endorsement by the U.S. Government.

Although this information product, for the most part, is in the public domain, it also may contain copyrighted materials as noted in the text. Permission to reproduce copyrighted items must be secured from the copyright owner.

Suggested citation:

Liedtke, T.L., Kock, T.J., and Hurst, W., 2018, Passage survival of juvenile steelhead, coho salmon, and Chinook salmon in Lake Scanewa and at Cowlitz Falls Dam, Cowlitz River, Washington, 2010-16: U.S. Geological Survey Open-File Report 2018-1050, 44 p., https://doi.org/10.3133/ofr20181050.

ISSN 2331-1258 (online) 


\section{Acknowledgments}

These studies were made possible due to the collaboration of many people and organizations. First and foremost we would like to thank Mike Kohn with Lewis County Public Utility District and Debbie Carlson with Bonneville Power Administration for initiating and funding these research efforts. John Serl with the Washington Department of Fish and Wildlife, Wade and Diane Heimbigner with the Pacific States Marine Fisheries Commission, and the staff of the Cowlitz Falls Fish Facility collected and held fish for tagging and monitored collected fish to identify study fish that were collected; their hard work is greatly appreciated. Joe First, with Lewis County Public Utility District and the Cowlitz Falls Dam staff provided access and support for the installation and maintenance of monitoring equipment. Brian Ekstrom, Ryan Tomka, and Andrew Wells with the U.S. Geological Survey, Columbia River Research Laboratory made significant contributions to the field activities and data summaries. Funding for this research was provided through collaborative efforts between Tacoma Power and Lewis County Public Utility District. 
This page left intentionally blank 


\section{Contents}

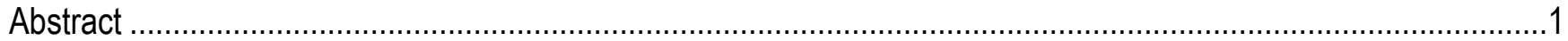

Chapter A. Reservoir Passage Survival of Juvenile Steelhead, Coho Salmon, and Chinook Salmon in Lake

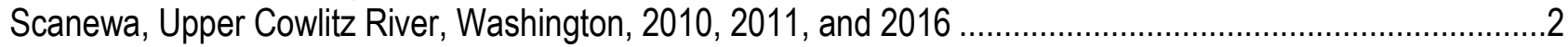

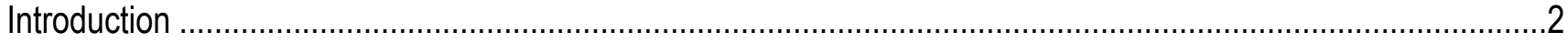

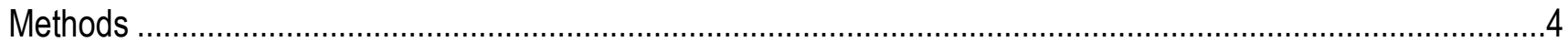

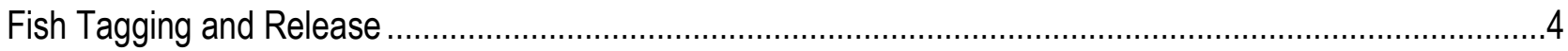

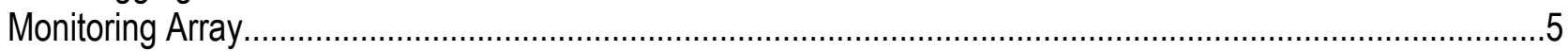

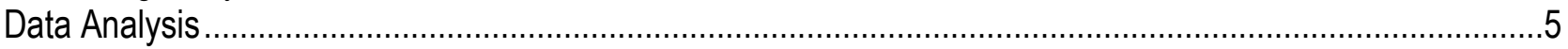

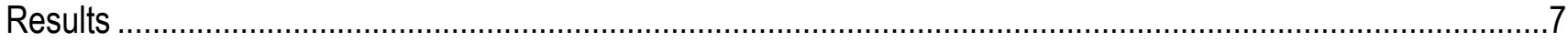

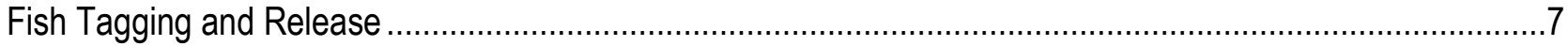

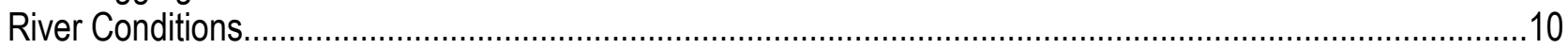

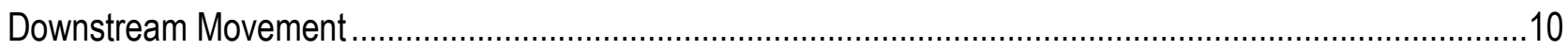

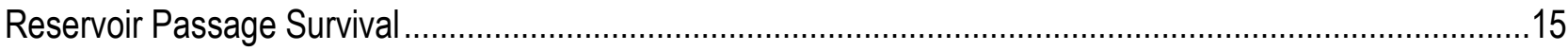

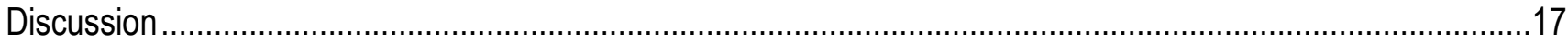

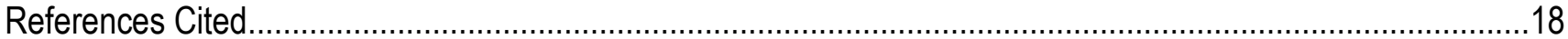

Chapter B. Dam Passage Survival of Juvenile Steelhead, Coho Salmon, and Chinook Salmon at Cowlitz Falls

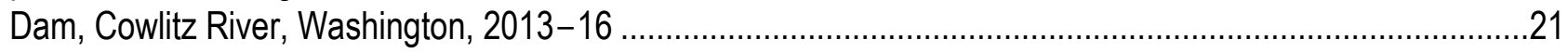

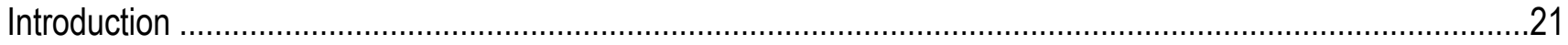

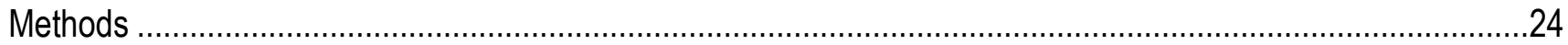

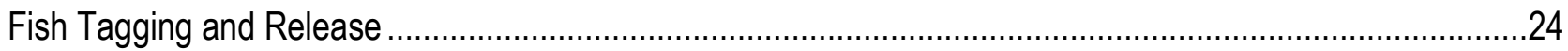

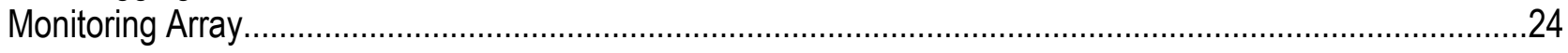

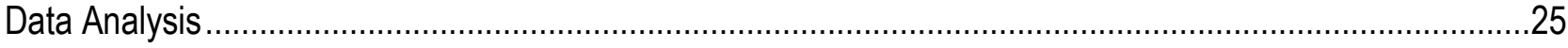

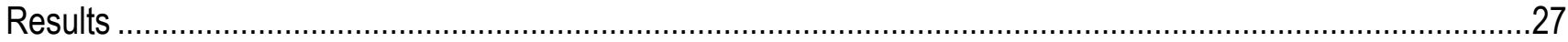

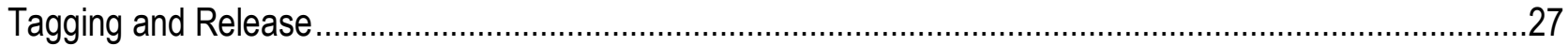

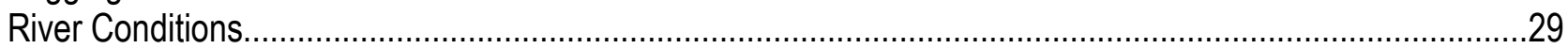

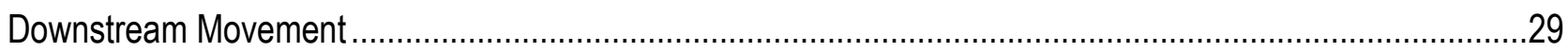

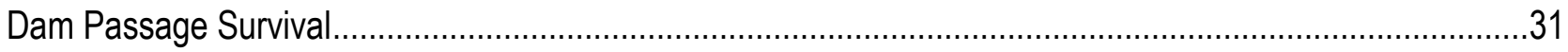

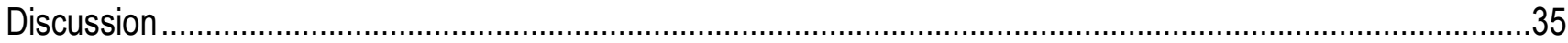

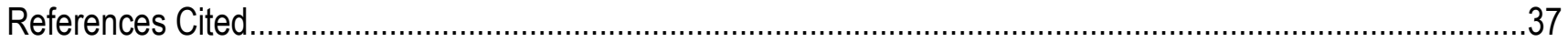

Appendix 1. Summary of Radio Transmitter Failures Associated with the 2016 Cowlitz River Evaluations............39 


\section{Figures}

Figure A1. Schematic map of the upper Cowlitz River Basin showing Cowlitz Falls Dam, Lake Scanewa, and the Cowlitz and Cispus Rivers, Washington...

Figure A2. Total discharge for the Cowlitz River (USGS streamgage 14233500), Washington, for April 1 through August 31, 2010-16 and a 10-year average (2007-16)...

Figure A3. Percentage of tagged juvenile steelhead, coho salmon, and Chinook salmon that were not detected in the forebay of Cowlitz Falls Dam, Washington, as a function of time after release, 2010, 2011, and 2016.

Figure A4. Size distributions of all juvenile steelhead, coho salmon, and Chinook salmon collected at the Cowlitz Falls Fish Facility (solid circles), Washington, during 2010, 2011, and 2016, and those that were radio-tagged and released to estimate reservoir passage survival (open circles)

Figure A5. Operating life of radio transmitters used to evaluate reservoir passage survival in Lake Scanewa, Washington, during 2010, 2011, and 2016

Figure B1. Schematic map of the upper Cowlitz River Basin showing Cowlitz Falls Dam, Lake Scanewa, and the Cowlitz and Cispus Rivers, Washington

Figure B2. Image of Cowlitz Falls Dam, Washington, with overlays showing how survival was estimated for treatment fish $\left(S_{T}\right)$, control fish $\left(S_{C}\right)$, and for dam passage survival $\left(S_{D a m}\right)$.

Figure B3. Percentage of tagged juvenile Chinook salmon that passed Cowlitz Falls Dam, Washington, that were not detected on fixed sites at the head of Riffe Lake as a function of time after release, 2013-14

Figure B4. Size distributions of all juvenile steelhead and coho salmon collected at the Cowlitz Falls Fish Facility (solid circles), Washington, during 2015-2016, and those that were radio-tagged and released to estimate reservoir passage survival (open circles).

Figure B5. Size distributions of all juvenile Chinook salmon collected at the Cowlitz Falls Fish Facility (solid circles), Washington, during 2013-14, and those that were radio-tagged and released to estimate reservoir passage survival (open circles)

Figure B6. Operating life of radio transmitters used to evaluate dam passage survival at Cowlitz Falls Dam, Washington, 2013-14

\section{Tables}

Table A1. Summary of radio transmitters used to monitor juvenile steelhead, coho salmon, and Chinook salmon collected and tagged at Cowlitz Falls Fish Facility, Washington, 2010, 2011, and 2016

Table A2. Total number of radio-tagged juvenile steelhead, coho salmon and Chinook salmon released in the Cowlitz and Cispus Rivers, Washington, to assess reservoir passage survival, 2010

Table A3. Total number of radio-tagged juvenile steelhead, coho salmon and Chinook salmon released in the Cowlitz and Cispus Rivers, Washington, to assess reservoir passage survival, 2011

Table A4. Total number of radio-tagged juvenile steelhead, coho salmon and Chinook salmon released in the Cowlitz and Cispus Rivers, Washington, to assess reservoir passage survival, 2016

Table A5. Number of tagged steelhead, coho salmon, and Chinook salmon euthanized, released, and detected, in Lake Sanewa or at Cowlitz Falls Dam, Washington, 2010-11

Table A6. Estimates of survival probabilities for juvenile steelhead, coho salmon, and Chinook salmon migrating through Lake Scanewa, Cowlitz River, Washington, 2010, 2011, and 2016.

Table B1. Summary of radio transmitters, including model, weight, and operating life used to monitor juvenile steelhead, coho salmon, and Chinook salmon collected and tagged at Cowlitz Falls Fish Facility, Washington, 2013-16

Table B2. Total number of radio-tagged juvenile Chinook salmon released into Lake Scanewa and the Cowlitz Falls Dam tailrace, Washington, to assess dam passage survival, 2013 
Table B3. Total number of radio-tagged juvenile Chinook salmon released into Lake Scanewa and the Cowlitz Falls Dam tailrace, Washington, to assess dam passage survival, 2014

Table B4. Total number of radio-tagged juvenile steelhead and coho salmon released into Lake Scanewa and the Cowlitz Falls Dam tailrace, Washington, to assess dam passage survival, 2015

Table B5. Total number of radio-tagged juvenile steelhead and coho salmon released into Lake Scanewa and the Cowlitz Falls Dam tailrace to assess dam passage survival, 2016

Table B6. Fates of radio-tagged juvenile steelhead, coho salmon, and Chinook salmon released into Lake

Scanewa to assess dam passage survival, 2013-16.

Table B7. Number of tagged steelhead, coho salmon, and Chinook salmon euthanized, released, and detected at Cowlitz Falls Dam, Washington, 2013-16

Table B8. Estimates of survival probabilities for juvenile Chinook salmon that passed Cowlitz Falls

Dam, Cowlitz River, Washington, 2013-14

\section{Conversion Factors}

U.S. customary units to International System of Units

\begin{tabular}{lll}
\hline \multicolumn{1}{c}{ Multiply } & To obtain \\
\hline & Length & \\
\hline foot $(\mathrm{ft})$ & 0.3048 & meter $(\mathrm{m})$ \\
\hline & Flow rate & \\
\hline cubic foot per second $\left(\mathrm{ft}^{3} / \mathrm{s}\right)$ & 0.02832 & cubic meter per second $\left(\mathrm{m}^{3} / \mathrm{s}\right)$ \\
\hline
\end{tabular}

International System of Units to U.S. customary units

\begin{tabular}{|c|c|c|}
\hline Multiply & By & To obtain \\
\hline \multicolumn{3}{|c|}{ Length } \\
\hline millimeter $(\mathrm{mm})$ & 0.03937 & inch (in.) \\
\hline kilometer $(\mathrm{km})$ & 0.6214 & mile (mi) \\
\hline \multicolumn{3}{|c|}{ Volume } \\
\hline liter $(\mathrm{L})$ & 33.81402 & ounce, fluid (fl. oz) \\
\hline \multicolumn{3}{|c|}{ Flow rate } \\
\hline cubic meter per second $\left(\mathrm{m}^{3} / \mathrm{s}\right)$ & 35.31 & cubic foot per second $\left(\mathrm{ft}^{3} / \mathrm{s}\right)$ \\
\hline \multicolumn{3}{|c|}{ Mass } \\
\hline $\operatorname{gram}(\mathrm{g})$ & 0.03527 & ounce, avoirdupois (oz) \\
\hline
\end{tabular}

Temperature in degrees Celsius $\left({ }^{\circ} \mathrm{C}\right)$ may be converted to degrees Fahrenheit $\left({ }^{\circ} \mathrm{F}\right)$ as ${ }^{\circ} \mathrm{F}=\left(1.8 \times{ }^{\circ} \mathrm{C}\right)+32$. 
This page left intentionally blank 


\title{
Passage Survival of Juvenile Steelhead, Coho Salmon, and Chinook Salmon in Lake Scanewa and at Cowlitz Falls Dam, Cowlitz River, Washington, 2010-16
}

\author{
By Theresa L. Liedtke, Tobias J. Kock, and William R. Hurst
}

\begin{abstract}
A multi-year evaluation was conducted during 2010-16 to evaluate passage survival of juvenile steelhead (Oncorhynchus mykiss), Chinook salmon (O. tshawytscha), and coho salmon (O. kisutch) in Lake Scanewa, and at Cowlitz Falls Dam in the upper Cowlitz River Basin, Washington. Reservoir passage survival was evaluated in 2010, 2011, and 2016, and included the tagging and release of 1,127 juvenile salmonids. Tagged fish were released directly into the Cowlitz and Cispus Rivers, 22.3 and 8.9 $\mathrm{km}$, respectively, upstream of the reservoir, and were monitored as they moved downstream into, and through the reservoir. A single release-recapture survival model was used to analyze detection records and estimate reservoir passage survival, which was defined as successful passage from reservoir entry to arrival at Cowlitz Falls Dam. Tagged fish generally moved quickly downstream of the release sites and, on average, arrived in the dam forebay within $2 \mathrm{~d}$ of release. Median travel time from release to first detection at the dam ranged from 0.23 to $0.96 \mathrm{~d}$ for juvenile steelhead, from 0.15 to $1.11 \mathrm{~d}$ for juvenile coho salmon, and from 0.18 to $1.89 \mathrm{~d}$ for juvenile Chinook salmon. Minimum reservoir passage survival probabilities were 0.960 for steelhead, 0.855 for coho salmon and 0.900 for Chinook salmon.

Dam passage survival was evaluated at the pilot-study level during 2013-16 and included the tagging and release of 2,512 juvenile salmonids. Juvenile Chinook salmon were evaluated during 201314, and juvenile steelhead and coho salmon were evaluated during 2015-16. A paired-release study design was used that included release sites located upstream and downstream of Cowlitz Falls Dam. The downstream release site was positioned at the downstream margin of the dam's tailrace, which allowed dam passage survival to be measured in a manner that included mortality that occurred in the passage route and in the dam tailrace. More than one-half of the tagged Chinook salmon (52 percent) released upstream of Cowlitz Falls Dam moved downstream and passed the project; the remaining fish either remained upstream of the dam (37 percent) or were collected (11 percent). In 2015 and 2016, collection efficiencies at Cowlitz Falls Dam were abnormally high for juvenile steelhead and coho salmon, which resulted in few fish passing the dam. Seven percent of the tagged steelhead ( 40 fish) and 4 percent of the tagged coho salmon (18 fish) released upstream of the dam eventually passed the project, but these low numbers of fish precluded the estimation of meaningful survival estimates. Dam passage survival probability estimates for juvenile Chinook salmon were 0.828 in 2013 and 0.861 in 2014, lower than previously reported for turbine-specific passage Cowlitz Falls Dam.
\end{abstract}




\section{Chapter A. Reservoir Passage Survival of Juvenile Steelhead, Coho Salmon, and Chinook Salmon in Lake Scanewa, Upper Cowlitz River, Washington, 2010, 2011, and 2016}

Introduction

In the early 1990s, the Lewis County Public Utility District (LCPUD) and Bonneville Power Administration jointly built Cowlitz Falls Dam in the upper Cowlitz River Basin, Washington. Construction of the dam, which is located at river kilometer (rkm) 142.6, was completed in 1994. The confluence of the Cowlitz and Cispus Rivers is located approximately $2 \mathrm{rkm}$ upstream of Cowlitz Falls Dam, near the center of Lake Scanewa (fig. A1), which is the reservoir created by the dam. The Cowlitz and Cispus Rivers historically supported anadromous fish populations until the 1960s, when the construction of Mayfield Dam (rkm 83.7) and Mossyrock Dam (rkm 107.0) eliminated fish passage into upstream areas. In the early 1990s, reintroduction efforts began that included trap-and-haul operations for adult steelhead (Oncorhynchus mykiss), Chinook salmon (O. tshawytscha), coho salmon (O. kisutch), and coastal cutthroat trout (O. clarkii clarkii) that were released upstream of Cowlitz Falls Dam. These efforts lead to the successful re-establishment of anadromous fish populations upstream of the dam, based on annual collection of thousands of juvenile outmigrants (Serl and Morrill, 2010) at the Cowlitz Falls Fish Facility (CFFF), located at Cowlitz Falls Dam.

Dams, and the reservoirs they create, have been shown to negatively affect populations of juvenile anadromous fish species. In undeveloped systems, juvenile salmon and steelhead typically outmigrate during spring and early summer when water temperatures are cool and discharge is high. However, when dams are constructed, reservoirs are created within these migration corridors, migration timing is altered, some fish become entrapped and residualize, and substantial predation can occur (Liedtke and others, 2009; Keefer and others, 2012, 2013; Brandt and others, 2016). To effectively manage fish populations in impounded systems, resource managers require information on juvenile salmon and steelhead migration survival rates.

Lake Scanewa is a small reservoir (247 ha) that normally would likely have limited effects on downstream migrants in the Cowlitz River. However, a nonnative population of rainbow trout $(O$. mykiss) is annually stocked into the reservoir and research has shown that some of these fish prey on juvenile salmonids (Tipping and Serl, 2000; Liedtke and others, 2011). The LCPUD is required by the Federal Energy Regulatory Commission (1986) to provide a recreational trout fishery in Lake Scanewa to help mitigate for lost fishing opportunities that resulted from the construction of Cowlitz Falls Dam. To meet this requirement, LCPUD funds a trout stocking program that includes the release of 20,000 hatchery-reared rainbow trout into the reservoir during June-August each year (Liedtke and others, 2011). Studies conducted during 2000 and 2011 identified juvenile salmon in the stomach contents of rainbow trout caught by anglers in Lake Scanewa, confirming that predation occurs (Tipping and Serl, 2000; Liedtke and others, 2011). 
We conducted an evaluation during 2010, 2011, and 2016 to estimate reservoir passage survival of juvenile steelhead, coho salmon, and Chinook salmon in Lake Scanewa. Juvenile salmon and steelhead were tagged with radio transmitters and released upstream of the reservoir. Monitoring sites detected fish as they arrived in the reservoir and eventually at Cowlitz Falls Dam. The primary objective of this study was to estimate reservoir passage survival of downstream migrants, from the point of reservoir entry to arrival at Cowlitz Falls Dam. In Chapter B of this report, we describe research conducted to evaluate dam passage survival at Cowlitz Falls Dam.

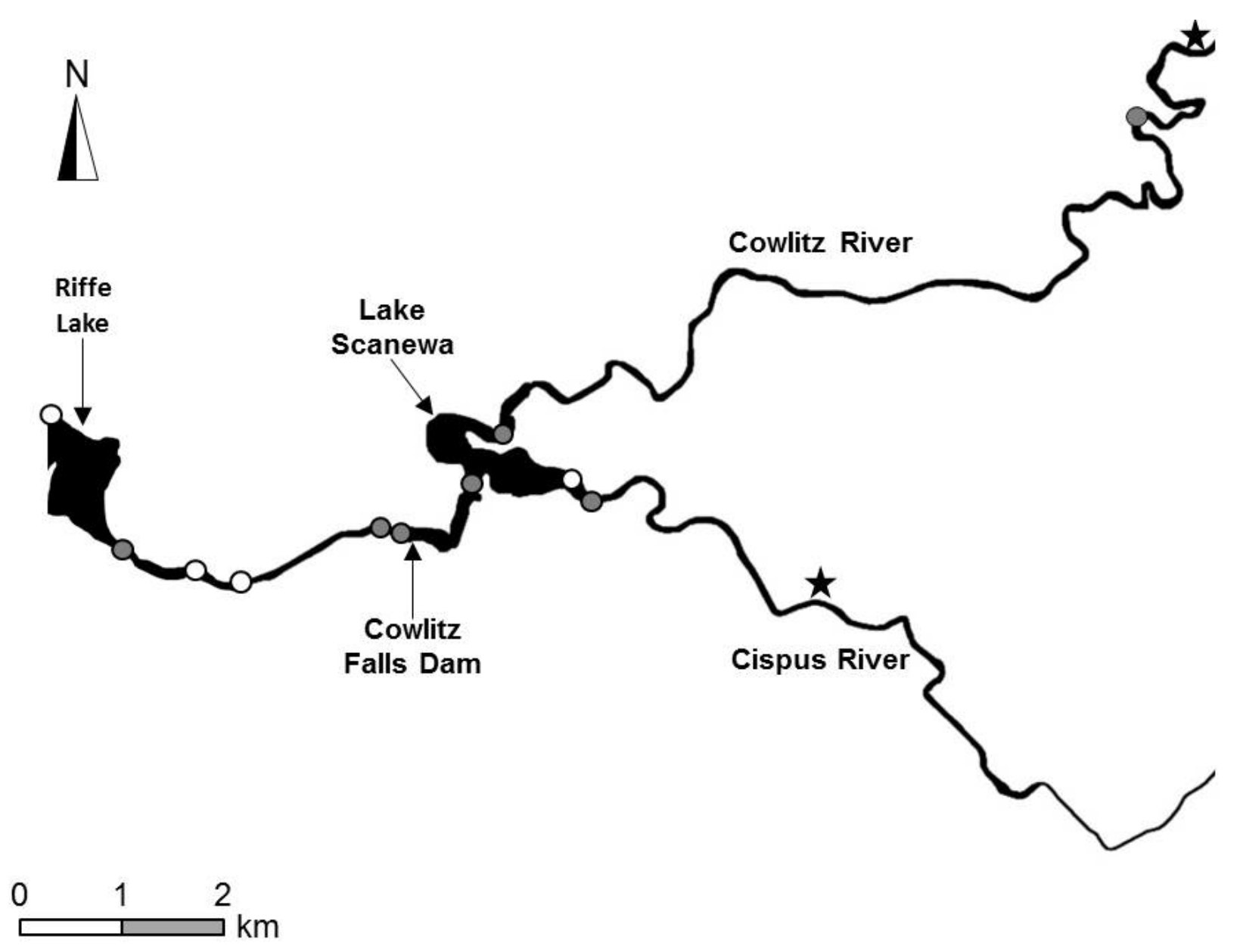

Figure A1. Schematic map of the upper Cowlitz River Basin showing Cowlitz Falls Dam, Lake Scanewa, and the Cowlitz and Cispus Rivers, Washington. Locations of fixed telemetry monitoring sites that were used to assess reservoir passage survival in 2010, 2011, and 2016 also are shown. Fixed telemetry sites used during every study year are shown by shaded circles. Fixed telemetry sites that were present during some study years are shown by open circles. Release locations for tagged fish are shown as stars. 


\section{Methods}

\section{Fish Tagging and Release}

Juvenile steelhead, coho salmon, and Chinook salmon were collected for tagging at the CFFF. Fish tagging and release were targeted to occur during the central 90th percentile of the historical run timing at the CFFF for each species studied. Run timing was determined by averaging daily collection numbers from annual fish collection records at the CFFF to determine the dates of the 5th and 95th percentiles of each run. These dates were used as the starting and ending points for tagging periods of each species. Fish were tagged and released one time each week during each release period, and weekly releases comprised similar numbers of fish.

Fish were collected $1 \mathrm{~d}$ prior to tagging and were held overnight in 95-L containers (maximum holding density $=20 \mathrm{~g}$ of fish/L of water) with flow-through river water. Radio transmitters (Lotek Wireless Inc., Newmarket, Ontario, Canada) were surgically implanted using methods described by Liedtke and others (2012). Transmitter model varied among years (table A1). After tagging, fish were placed into 19-L floating buckets ( 2 or 3 fish per bucket) in a 2,039-L tank at the CFFF. The following day, buckets were transferred to a 1,189-L aluminum transport tank full of river water. Dissolved oxygen concentrations were maintained from 100 to 120 percent using bottled oxygen and diffusers. Fish were then transported to sites upstream of Cowlitz Falls Dam for release.

Tagged fish were released at multiple locations during this study. The Cowlitz River release site was located 22.3 rkm upstream of Cowlitz Falls Dam and the Cispus River release site was located 8.9 rkm upstream of the dam (fig. A1). Approximate travel times were 30 and $45 \mathrm{~min}$ from the CFFF to the Cowlitz River release site and Cispus River release site, respectively. For some releases, water temperatures at the river release sites were more than $2{ }^{\circ} \mathrm{C}$ colder than water temperature at the CFFF (and in the fish transport container). To reduce thermal stress of fish, blocks of ice (made from river water) were placed in the transport container to slowly lower water temperature during transport. Transport tank water temperature was monitored to ensure decreases greater than $2{ }^{\circ} \mathrm{C}$ per hour did not occur.

Table A1. Summary of radio transmitters used to monitor juvenile steelhead, coho salmon, and Chinook salmon collected and tagged at Cowlitz Falls Fish Facility, Washington, 2010, 2011, and 2016.

\begin{tabular}{llcc}
\hline Year & Transmitter model & $\begin{array}{c}\text { Weight } \\
\text { in air }(\mathbf{g})\end{array}$ & $\begin{array}{c}\text { Expected } \\
\text { operating } \\
\text { life }(\mathbf{d})\end{array}$ \\
\hline 2010 & NTC-M-3 & 0.55 & 41 \\
2011 & NTC-M-2 & 0.43 & 33 \\
2016 & NTQ-2 & 0.31 & 27 \\
\hline
\end{tabular}




\section{Monitoring Array}

Tagged fish were monitored using a series of fixed-location monitoring sites throughout the study area. Aerial monitoring arrays were the primary monitoring approach and were composed of a pair of three-element Yagi antennas connected to a radiotelemetry receiver (Model SRX 400 ${ }^{\odot}$; Lotek Wireless Inc., Newmarket, Ontario, Canada; Orion receiver ${ }^{\odot}$; Sigma Eight Inc., Newmarket, Ontario, Canada). To assess reservoir passage survival in Lake Scanewa, monitoring sites were concentrated in areas upstream of Cowlitz Falls Dam, including the upper Cowlitz River, the Cowlitz and Cispus arms of Lake Scanewa, and the Cowlitz Falls Dam forebay. The locations of aerial monitoring sites upstream of the dam were on the Cowlitz River (19.7 rkm upstream of Cowlitz Falls Dam), on the Cispus River (3.4 rkm upstream of Cowlitz Fall Dam), and at two locations on Lake Scanewa (3.9 rkm upstream of Cowlitz Falls Dam and 1.3 rkm upstream of Cowlitz Falls Dam: fig. A1). Underwater monitoring sites were installed throughout the Cowlitz Falls Dam's fish collection system and in the fish collection facility to document the collection of radio-tagged fish. The movement patterns of fish that avoided capture in the fish collection system and passed the dam through the turbines or spillbays was monitored using three additional sites located in the dam tailrace $(0.2$ and $0.3 \mathrm{rkm}$ downstream of Cowlitz Falls Dam) and near the head of Riffe Lake at Taidnapam Bridge (4.8 rkm downstream of Cowlitz Falls Dam). During 2016, four additional monitoring sites were established downstream of Cowlitz Falls Dam to increase the opportunity to detect fish and confirm dam passage. These sites were located 2.8, 3.5 , and $7.1 \mathrm{rkm}$ (two sites) downstream of the dam.

\section{Data Analysis}

We used a single release-recapture study design (Skalski and others, 1998; Muir and others, 2001) to assess reservoir passage survival in Lake Scanewa. The term "single-release" refers to a study design where groups of fish are released at a single location and survival estimates are obtained as fish move downstream through individual reaches. For this study, the single release study design was modified slightly to include two release locations. Tagged fish were released immediately upstream of the upper bounds of Lake Scanewa in the Cowlitz and Cispus Rivers. Detection gates (locations of monitoring equipment where tagged fish can be detected) collected information as fish entered Lake Scanewa, arrived at Cowlitz Falls Dam, were collected, passed the dam, or remained in the reservoir. Estimating reservoir passage survival required determining how many fish survived from reservoir entry to arrival at the dam. Fish released in the Cowlitz River were used to estimate reservoir passage survival from entry to the Cowlitz River Arm to arrival at Cowlitz Falls Dam. Fish released in the Cispus River were used to estimate reservoir passage survival from entry to the Cispus River arm to arrival at Cowlitz Falls Dam. Telemetry monitoring sites located at the upstream reservoir boundaries on the Cowlitz and Cispus arms of Lake Scanewa monitored fish entering the reservoir from each of the upstream release sites. Telemetry monitoring sites at Cowlitz Falls Dam monitored fish that arrived in the dam forebay. A combination of fixed monitoring sites located downstream of the dam and in the CFFF was used to identify fish that either passed the dam or were collected at the dam. 
Detection records were queried to create three-digit capture histories that summarized detection information for each tagged fish. Capture histories used either a " 1 " or a " 0 " to describe whether or not fish were known to be present at specific locations in the study area. The first digit in the capture history represented fish presence at the head of Lake Scanewa. Because all fish were released at this location every capture history included a " 1 " as the first digit. The second digit in the capture history represented fish arriving at Cowlitz Falls Dam: fish detected at the dam were assigned a "1" and undetected fish at the dam were assigned a "0". Finally, the third digit represented fish passing the dam, and included fish that passed downstream into the tailrace, or fish that were collected at the fish facility. Fish that were detected in the river downstream of the dam or in the fish facility were assigned a "1" and those that remained in Lake Scanewa were assigned a " 0 ". As an example, the capture history " 101 " describes a fish that was released at the head of Lake Scanewa (1), was not detected in the forebay of Cowlitz Falls Dam (0), but was later detected either downstream of the dam, or in the fish facility (1).

A Cormack-Jolly-Seber ([CJS]; Cormack, 1964; Jolly, 1965; Seber, 1965) mark-recapture model was developed and data were analyzed using the RMark package (Laake, 2013), which calls program MARK (White and Burnham, 1999) from within R (R Core Team, 2013). The CJS model allowed detection probabilities to vary by detection site, and survival probabilities to vary by year, release site, and detection site. The model structure allowed survival probability estimates for groups of fish released in the Cowlitz arm and Cispus arm of Lake Scanewa to be calculated for each study year. Data from steelhead, coho salmon, and Chinook salmon were analyzed separately using the same model.

The single release-recapture study design is subject to eight assumptions that are described in Skalski and others (1998). These include:

1. Test fish are representative of the population of inference.

2. Test conditions are representative of the conditions of inference.

3. The number of fish released is exactly known.

4. Tag codes are accurately recorded at the time of tagging and at all detection sites, and the status of each fish (alive or dead) is correctly assessed.

5. For replicated studies, data from different releases are statistically independent.

6. The fate of each fish is independent of the fates of all other fish.

7. All fish have equal survival and detection probabilities.

8. Prior detection history has no effect on subsequent survival and detection probabilities. 
A critical part of conducting a telemetry-based smolt survival study is to ensure that negative or positive bias of the survival estimates is minimized. Negative bias in survival estimates can result from live fish that are moving through the study area with transmitters that are no longer functioning. Therefore, understanding the expected operating life of the transmitters was critical, and was developed through laboratory evaluations. Each year, a subset of radio transmitters (13-20 transmitters per year) was selected randomly from the group of transmitters used in the study. These transmitters were activated and placed in a fiberglass tank with flow-through river water at the USGS Columbia River Research Laboratory in Cook, Washington. A telemetry receiver monitored the transmitters until all transmitters had stopped operating. The observed operating life of each transmitter was calculated by subtracting the date and time when the transmitter began operating (activation time) from the date and time when it was last detected by the telemetry receiver. A potential source of positive bias in survival estimates is the detection of a dead fish with an active transmitter (Peven and others, 2005). It is possible for tagged dead fish to drift downstream and be detected by the monitoring array, making it difficult to distinguish it from a live fish moving downstream. A common method for testing this assumption is to tag euthanized fish, release them into the study area with live study fish, and monitor whether they are detected at downstream monitoring sites. Euthanized juvenile steelhead, coho salmon, and Chinook salmon were tagged and released across a range of river flows in 2010 and 2011 to evaluate this assumption.

\section{Results}

\section{Fish Tagging and Release}

A total of 1,127 juvenile steelhead, coho salmon, and Chinook salmon were radio-tagged and released to evaluate reservoir passage survival in Lake Scanewa during 2010, 2011, and 2016. Most of the fish (1,100 fish; tables A2, A3, A4) were released alive and monitored as they moved downstream. Twenty-seven ( 2.4 percent) of the tagged fish were euthanized prior to release to determine if they were detected on fixed sites in the monitoring array. The release of dead fish is part of testing assumption 4 of the single release-recapture study design (see section, "Methods: Data Analysis"). The tagged population comprised 476 steelhead (42.2 percent), 433 coho salmon (38.4 percent), and 218 Chinook salmon (19.3 percent). All three species were monitored during 2010 and 2011. Steelhead and coho salmon were monitored in 2016 (tables A2-A4). 
Table A2. Total number of radio-tagged juvenile steelhead, coho salmon and Chinook salmon released in the Cowlitz and Cispus Rivers, Washington, to assess reservoir passage survival, 2010.

[Numbers in parentheses are tagged fish that were euthanized prior to release to determine downstream drift patterns of dead fish]

\begin{tabular}{|c|c|c|c|c|c|c|c|}
\hline \multirow{2}{*}{ Month } & \multirow{2}{*}{ Week } & \multicolumn{2}{|c|}{ Steelhead } & \multicolumn{2}{|c|}{ Coho salmon } & \multicolumn{2}{|c|}{ Chinook salmon } \\
\hline & & Cowlitz & Cispus & Cowlitz & Cispus & Cowlitz & Cispus \\
\hline April & 4 & $3(1)$ & $3(1)$ & & & & \\
\hline May & 1 & 10 & 10 & & & & \\
\hline May & 2 & $7(1)$ & $7(1)$ & 3 & 2 & & \\
\hline May & 3 & 10 & 11 & $7(1)$ & $8(2)$ & & \\
\hline May & 4 & 7 & 6 & 6 & 5 & & \\
\hline June & 1 & 7 & 7 & $5(1)$ & $6(1)$ & & \\
\hline June & 2 & 6 & 7 & 5 & 5 & & \\
\hline June & 3 & & & 7 & $8(1)$ & & \\
\hline June & 4 & & & 5 & 5 & & \\
\hline June & 5 & & & & & 2 & 3 \\
\hline July & 1 & & & 5 & 5 & 3 & 2 \\
\hline July & 2 & & & 5 & 5 & $8(1)$ & $8(1)$ \\
\hline July & 3 & & & 2 & 1 & 6 & 6 \\
\hline July & 4 & & & & & 6 & 6 \\
\hline July & 5 & & & & & $9(1)$ & $9(1)$ \\
\hline August & 1 & & & & & 6 & 6 \\
\hline August & 2 & & & & & 5 & 5 \\
\hline August & 3 & & & & & 5 & 5 \\
\hline \multicolumn{2}{|c|}{ Total $=$} & $50(2)$ & $50(2)$ & $50(2)$ & $50(4)$ & $50(2)$ & $50(2)$ \\
\hline
\end{tabular}


Table A3. Total number of radio-tagged juvenile steelhead, coho salmon and Chinook salmon released in the Cowlitz and Cispus Rivers, Washington, to assess reservoir passage survival, 2011.

[Numbers in parentheses are tagged fish that were euthanized prior to release to determine downstream drift patterns of dead fish]

\begin{tabular}{|c|c|c|c|c|c|c|c|}
\hline \multirow{2}{*}{ Month } & \multirow{2}{*}{ Week } & \multicolumn{2}{|c|}{ Steelhead } & \multicolumn{2}{|c|}{ Coho salmon } & \multicolumn{2}{|c|}{ Chinook salmon } \\
\hline & & Cowlitz & Cispus & Cowlitz & Cispus & Cowlitz & Cispus \\
\hline April & 4 & 5 & 6 & & & & \\
\hline May & 1 & $11(1)$ & $11(1)$ & & & & \\
\hline May & 2 & $6(1)$ & 5 & 5 & 4 & & \\
\hline May & 3 & 5 & 6 & $5(1)$ & $4(1)$ & & \\
\hline May & 4 & $12(1)$ & $9(1)$ & 8 & 10 & & \\
\hline June & 1 & 5 & 7 & 5 & 5 & & \\
\hline June & 2 & 6 & 5 & $10(1)$ & $9(1)$ & & \\
\hline June & 3 & 4 & 3 & 4 & 5 & & \\
\hline June & 4 & 1 & 3 & 5 & 4 & & \\
\hline June & 5 & & & 4 & 5 & & \\
\hline July & 1 & & & 5 & 4 & & \\
\hline July & 2 & & & 3 & 3 & & \\
\hline July & 3 & & & 1 & 2 & & \\
\hline July & 4 & & & & & & \\
\hline July & 5 & & & & & 3 & 4 \\
\hline August & 1 & & & & & $20(1)$ & $17(1)$ \\
\hline August & 2 & & & & & 18 & 20 \\
\hline August & 3 & & & & & $14(1)$ & $14(1)$ \\
\hline \multicolumn{2}{|c|}{ Total $=$} & $55(3)$ & $55(2)$ & $55(2)$ & $55(2)$ & $55(2)$ & $55(2)$ \\
\hline
\end{tabular}

Table A4. Total number of radio-tagged juvenile steelhead, coho salmon and Chinook salmon released in the Cowlitz and Cispus Rivers, Washington, to assess reservoir passage survival, 2016.

\begin{tabular}{|c|c|c|c|c|c|}
\hline \multirow{2}{*}{ Month } & \multirow{2}{*}{ Week } & \multicolumn{2}{|c|}{ Steelhead } & \multicolumn{2}{|c|}{ Coho salmon } \\
\hline & & Cowlitz & Cispus & Cowlitz & Cispus \\
\hline April & 5 & 24 & 24 & & \\
\hline May & 1 & 26 & 26 & & \\
\hline May & 2 & 26 & 26 & & \\
\hline May & 3 & 20 & 20 & 10 & 10 \\
\hline May & 4 & 18 & 18 & 11 & 11 \\
\hline June & 1 & 15 & 14 & 13 & 13 \\
\hline June & 2 & & & 9 & 9 \\
\hline June & 3 & & & & \\
\hline June & 4 & & & & \\
\hline June & 5 & & & 64 & 63 \\
\hline \multicolumn{2}{|c|}{ Total $=$} & 129 & 128 & 107 & 106 \\
\hline
\end{tabular}




\section{River Conditions}

River discharge during the study years was variable. In 2010, the average (April 1-August) total discharge was similar to the 10-year (2007-16) average (fig. A2). The average flow conditions during 2011 were 130 percent of the 10-year average, with several high flow events (fig. A2). Finally, during 2016, the average flow conditions were low, only 79 percent of the 10 -year average, the second lowest flow year in the 10-year average (fig. A2).

\section{Downstream Movement}

Most fish moved downstream quickly following release and were detected in the forebay of Cowlitz Falls Dam. Median time from release to first detection in the forebay ranged from 0.23 to 0.96 $\mathrm{d}$ for juvenile steelhead, from 0.15 to $1.11 \mathrm{~d}$ for juvenile coho salmon, and from 0.18 to $1.89 \mathrm{~d}$ for juvenile Chinook salmon (fig. A3). In 2016 the mean time from release to first forebay detection was longer than in other years, likely due to the lower flow conditions (fig. A3). Similarly, for the Chinook salmon, downstream movement was slower in 2010 (an average flow year)than in 2011 when the average flow was higher (fig. A3). The percentage of fish detected in the dam forebay ranged from 90.0 to 98.8 percent for juvenile steelhead, from 91.8 to 98.0 percent for juvenile coho salmon, and from 90.1 to 99.1 percent for juvenile Chinook salmon. Maximum elapsed time from release to first detection in the forebay was $26.2 \mathrm{~d}$ for juvenile steelhead, $12.4 \mathrm{~d}$ for juvenile coho salmon, and $31.3 \mathrm{~d}$ for juvenile Chinook salmon. 


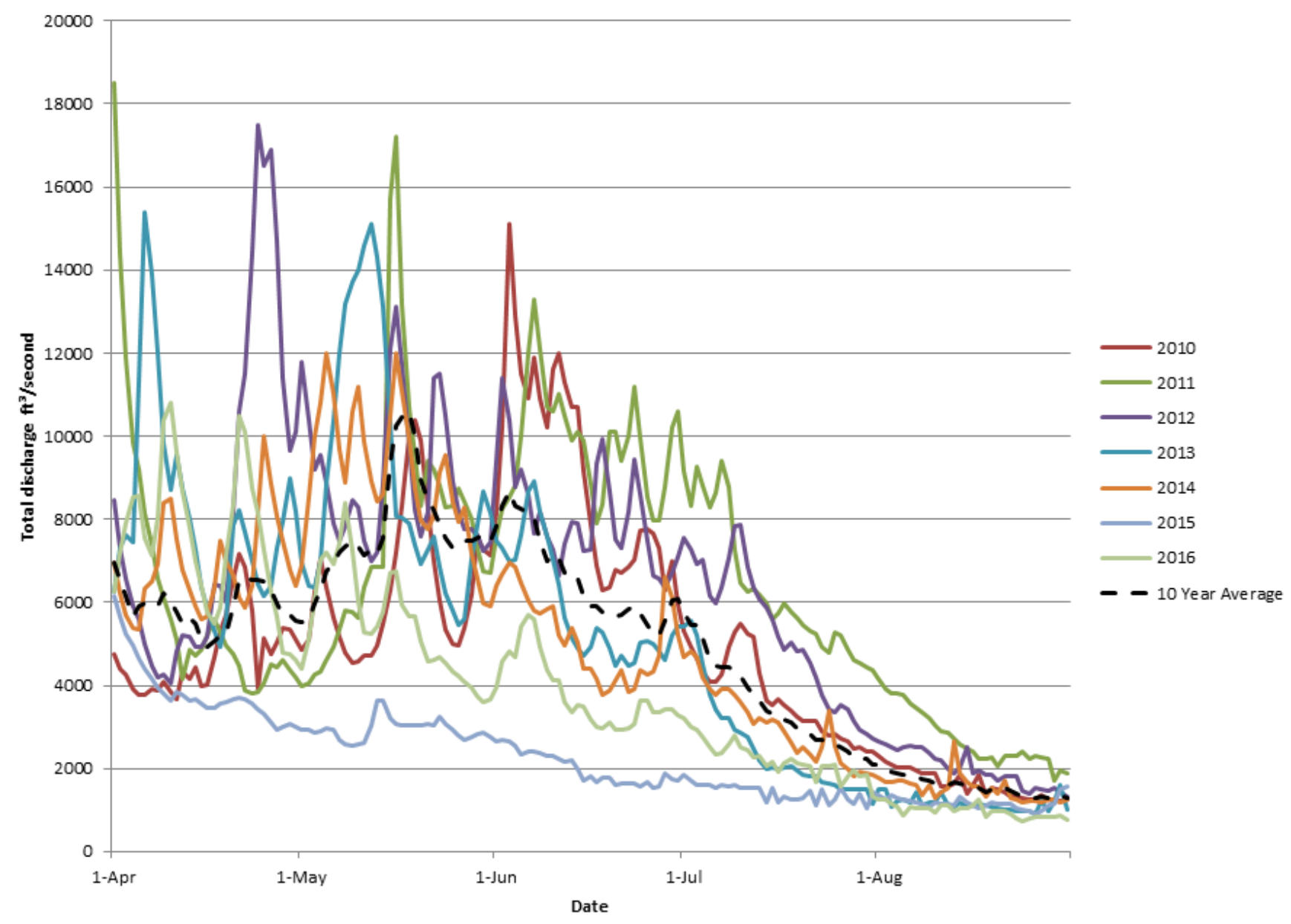

Figure A2. Total discharge for the Cowlitz River (USGS streamgage 14233500), Washington, for April 1 through August 31, 2010-16 and a 10-year average (2007-16). 

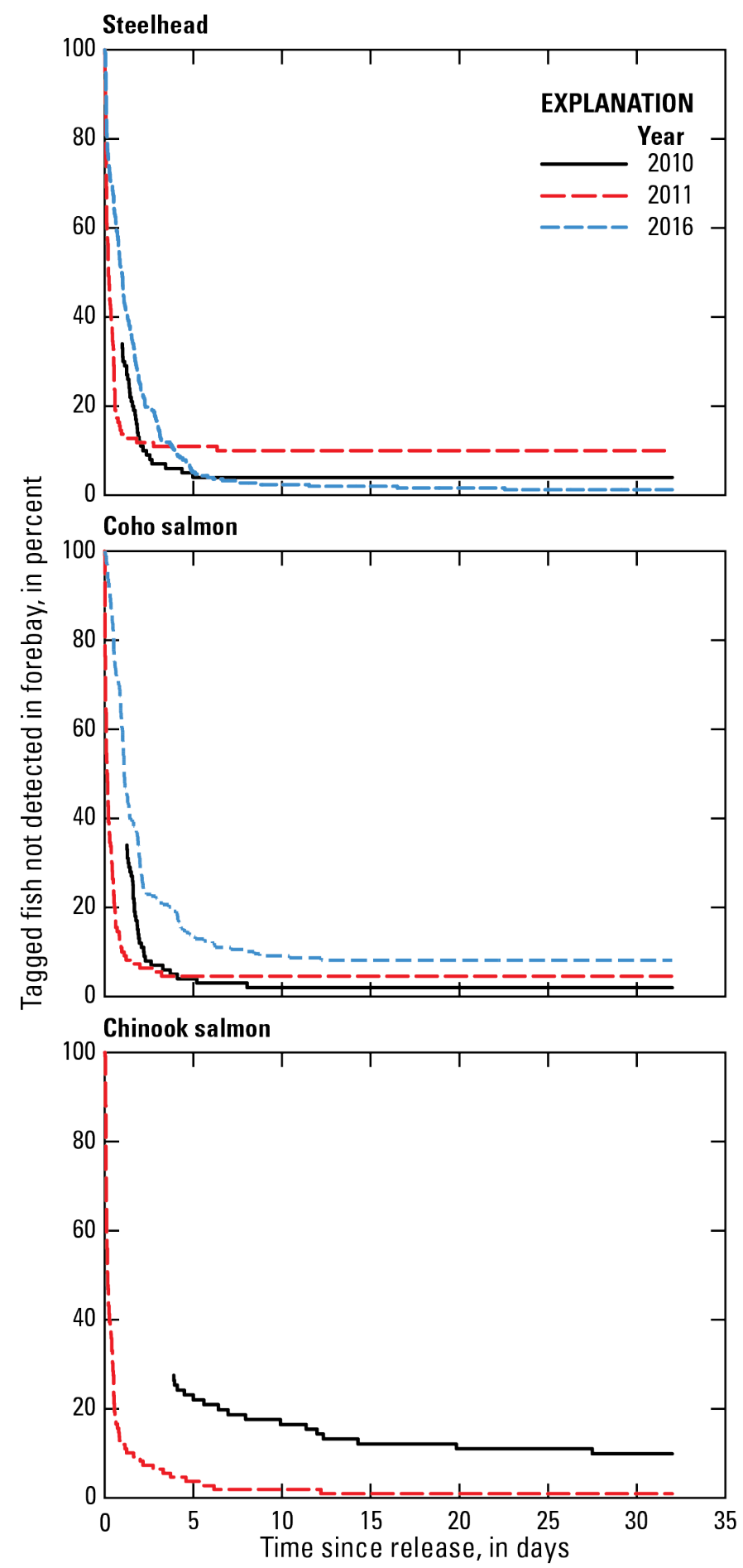

Figure A3. Percentage of tagged juvenile steelhead, coho salmon, and Chinook salmon that were not detected in the forebay of Cowlitz Falls Dam, Washington, as a function of time after release, 2010, 2011, and 2016. 

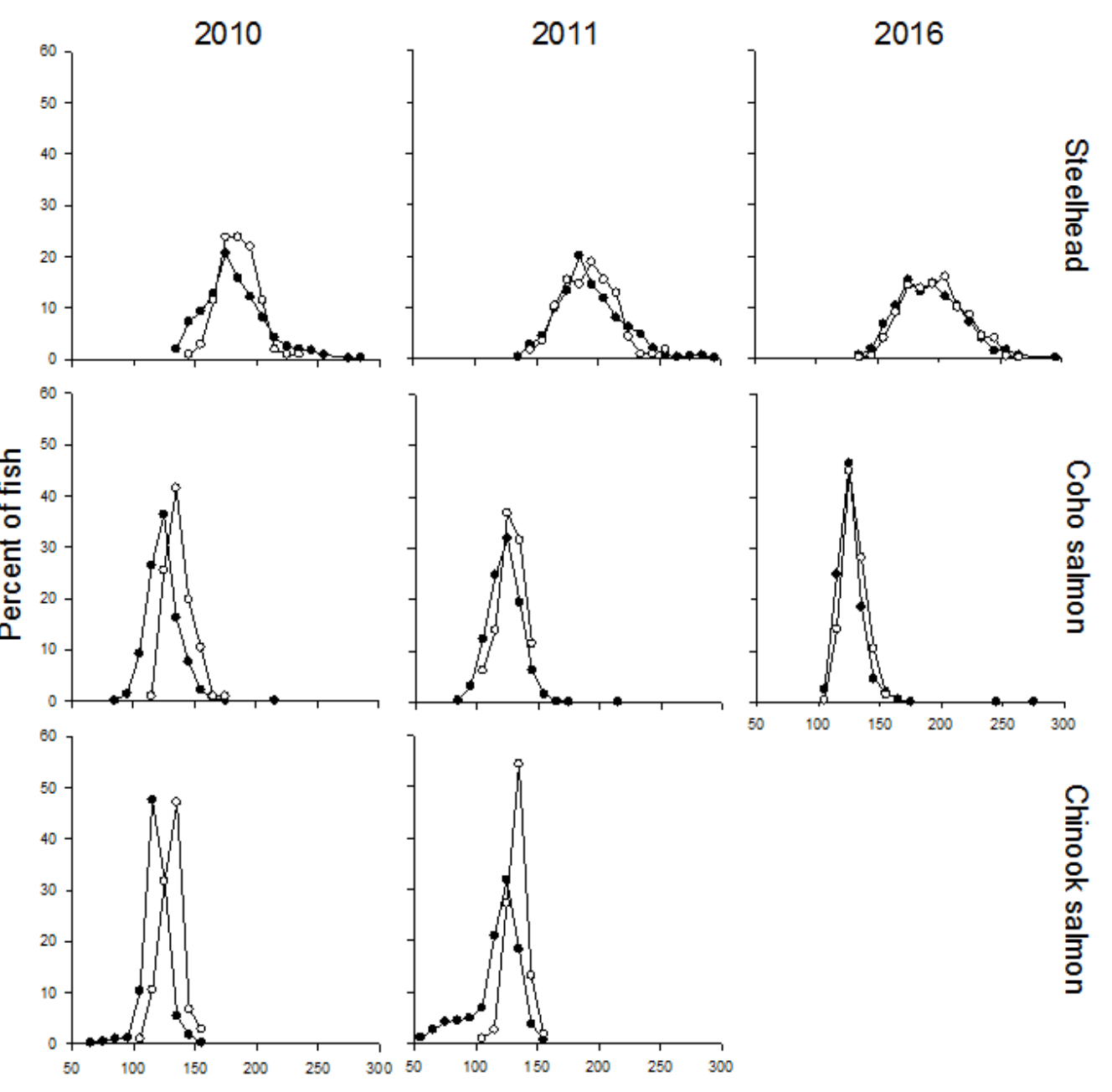

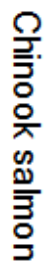

Figure A4. Size distributions of all juvenile steelhead, coho salmon, and Chinook salmon collected at the Cowlitz Falls Fish Facility (solid circles), Washington, during 2010, 2011, and 2016, and those that were radio-tagged and released to estimate reservoir passage survival (open circles). 


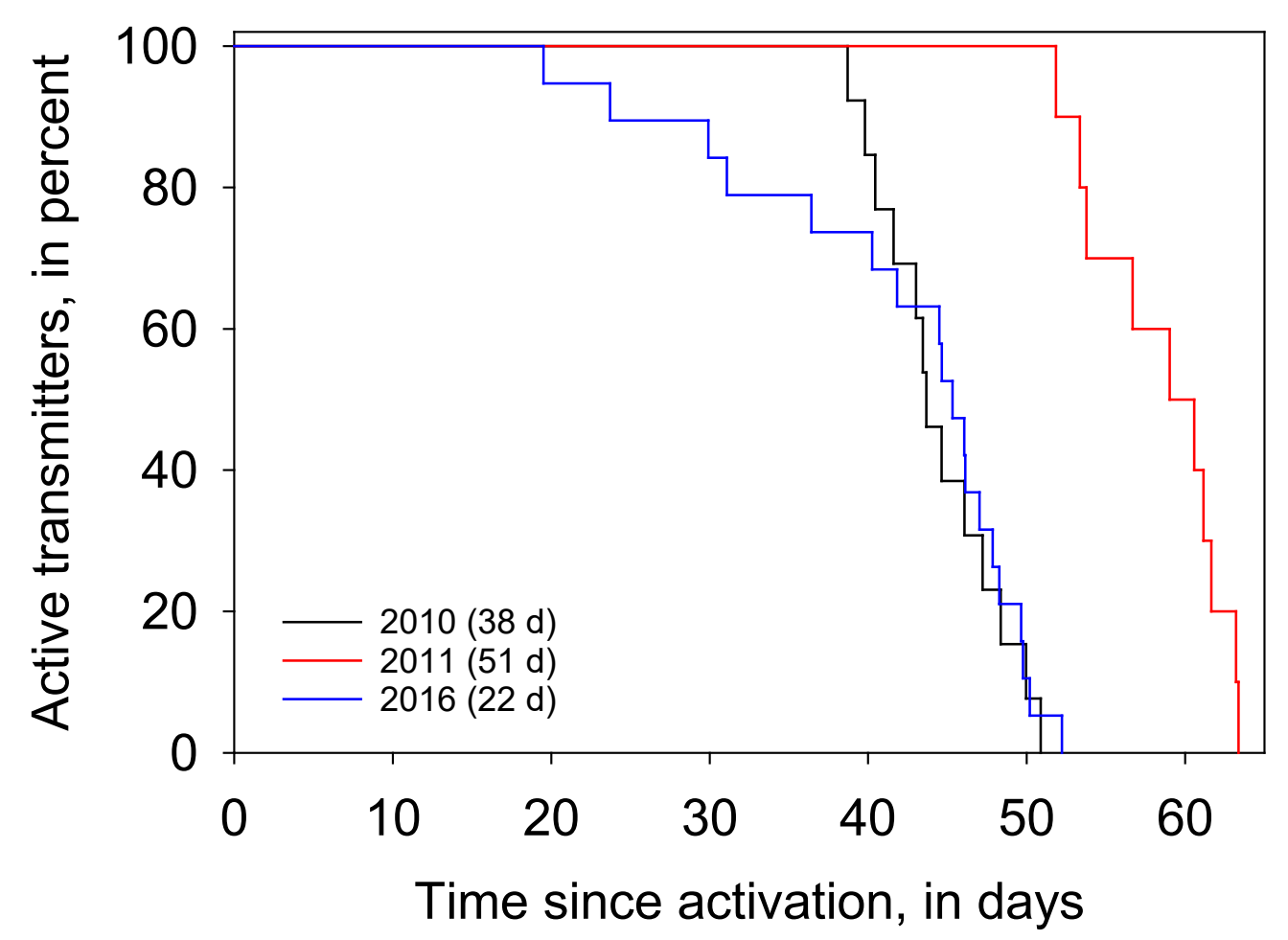

Figure A5. Operating life of radio transmitters used to evaluate reservoir passage survival in Lake Scanewa, Washington, during 2010, 2011, and 2016. The 90th percentile of the operating life of transmitters from each study year are shown in parentheses.

In 2016, a transmitter failure was identified for fish that moved downstream and were recollected at the CFFF. Staff at the CFFF observed that some of the collected fish had obvious incisions and sutures (evidence that they had been surgically implanted with a radio transmitter) but did not have a radio transmitter antenna trailing along the lateral side of the fish, as is typical (appendix 1). When we examined these fish, and removed the transmitter, we discovered that the antenna had become separated from the main body of the transmitter. This type of transmitter failure had not been observed in our previous Cowlitz River telemetry studies, or in any other published account. Through discussions with colleagues, we learned that similar issues were identified in a study on the Deschutes River during the same time (April-June 2016) (Gonzalo Mendez, Portland General Electric, oral commun.). The total number of radio-tagged steelhead and coho salmon collected at the CFFF in 2016 was 341 and 19 of these fish (5.6 percent) had transmitters with broken antennas (appendix 1). The tag failures were more common for coho salmon than for steelhead. There were 182 steelhead collected at the CFFF and four of these had broken antennas (2.2 percent). For coho salmon, 159 fish were collected and 15 had broken antennas (9.4 percent). Fish were collected at the CFFF with broken antennas as early as $3 \mathrm{~d}$ after they were released into the reservoir and as late as $27 \mathrm{~d}$. One fish was found without a trailing antenna within hours after tagging, as it was being transported to the reservoir for release. To better understand the rate of tag failure, we initiated a controlled laboratory study (appendix 1). In the laboratory tests, tag failures occurred between $4 \mathrm{~d}$ and $38 \mathrm{~d}$ after tagging (appendix 1). 


\section{Reservoir Passage Survival}

The single release-recapture study design used in this study is subject to eight assumptions described in Skalski and others (1998). For Assumption 1, study fish were randomly selected from the run-at-large that was collected at Cowlitz Falls Dam between the historical 5th and 95th percentiles of the run timing for each species. We used a maximum tag burden (transmitter weight in grams divided by fish weight in grams) of 5 percent to limit potential tag effects on study fish (Liedtke and others, 2012). This fish selection criterion limited our ability to tag the smallest fish in each population (fig. A4).

Our evaluations of transmitter life for each year of study suggest that premature tag failures were not likely to bias the study findings. Measuring transmitter life is part of evaluating the fourth and seventh model assumptions, as it informs the potential status of detected fish as alive or dead. For example, a live fish may carry a transmitter that stopped operating prior to the end of expected tag life, and could therefore be incorrectly assigned a fate of dead in the survival model. For assumption seven, fish with failed tags would not have equal detection probabilities compared to functional tags. The 90th percentile of the operating life of radio transmitters was determined to be 38,51 , and $22 \mathrm{~d}$ for the transmitters used in 2010, 2011, and 2016, respectively (fig. A5). In 2010, the first transmitter stopped operating $38.7 \mathrm{~d}$ after activation and the last transmitter stopped operating $50.9 \mathrm{~d}$ after activation. The shortest and longest tag life periods in 2011 were 51.9 and $63.4 \mathrm{~d}$, respectively. In 2016, the first tag stopped operating after $19.5 \mathrm{~d}$ and the last tag stopped operating after $52.2 \mathrm{~d}$. Based on these results and the fact that most fish arrived in the forebay of Cowlitz Falls Dam within $5 \mathrm{~d}$ of release (fig. A3), survival estimates are unlikely to be biased based on premature tag failures.

Our release and monitoring of euthanized tagged fish suggest a low risk of the inappropriate assignment of the status (alive or dead) of study fish and support the assessment that assumption four of the survival model was met. In total, 26 fish were tagged, euthanized, and released with live fish to determine if dead fish could drift downstream and be detected on monitoring sites. About one-third (34.6 percent) of the euthanized fish were detected in Lake Scanewa following release, but no fish were detected at Cowlitz Falls Dam (table A5). Based on this information, we do not believe that downstream drift of dead fish resulted in biased estimates of reservoir passage survival during the study.

Table A5. Number of tagged steelhead, coho salmon, and Chinook salmon euthanized, released, and detected, in Lake Sanewa or at Cowlitz Falls Dam, Washington, 2010-11.

\begin{tabular}{lccccc}
\hline \multicolumn{1}{c}{ Species } & Year & Not detected & $\begin{array}{c}\text { Detected in } \\
\text { Lake Scanewa }\end{array}$ & $\begin{array}{c}\text { Detected at } \\
\text { Cowlitz Falls Dam }\end{array}$ & Total \\
\hline Steelhead & 2010 & 3 & 1 & 0 & 4 \\
Coho salmon & 2010 & 4 & 1 & 0 & 5 \\
Chinook salmon & 2010 & 4 & 0 & 0 & 4 \\
Steelhead & 2011 & 2 & 3 & 0 & 5 \\
Coho salmon & 2011 & 3 & 1 & 0 & 4 \\
Chinook salmon & 2011 & 1 & 3 & 0 & 0 \\
\multicolumn{2}{c}{ Total $=$} & 17 & 9 & 0 & 26 \\
\hline
\end{tabular}


Some model assumptions were evaluated less rigorously or were assumed to have been met based on past studies. The third assumption (the number of fish released is precisely known) was met with rigorous accounting of the numbers of fish that were tagged and released. The remaining assumptions (assumptions two, five, six, and eight) are based on the test conditions and statistical independence. The hydrological conditions in the reservoir and at the dam were variable over the study years, but are presented and can be used to guide inferences made from our survival estimates, meeting the second assumption. During data analyses we review individual fish detection histories and gain an understanding of fish movements in the study area. Individual releases are compared to evaluate similarity (to test assumption five of independence of releases). Through these processes, and the knowledge that our study design was established to address model assumptions, we are confident that the all model assumptions were met.

Survival probability estimates suggest that reservoir passage survival was high for steelhead and coho salmon, but lower for Chinook salmon. Survival probabilities ranged from 0.960 to 1.000 for steelhead, from 0.855 to 1.000 for coho salmon, and from 0.900 to 0.927 for Chinook salmon (table A6). Estimates for coho salmon exceeded 0.945 for all release sites and study years, except for fish released into the Cispus River during 2016, when survival was estimated to be 0.855 (table A6).

Table A6. Estimates of survival probabilities for juvenile steelhead, coho salmon, and Chinook salmon migrating through Lake Scanewa, Cowlitz River, Washington, 2010, 2011, and 2016.

[Fish were released upstream of Lake Scanewa in the Cowlitz and Cispus Rivers. Standard errors of survival probability estimates are in parentheses]

\begin{tabular}{ccc}
\hline Year & Cowlitz River & Cispus River \\
\hline \multicolumn{3}{c}{ Steelhead } \\
2010 & 1.000 & $0.960(0.028)$ \\
2011 & 1.000 & $0.964(0.025)$ \\
\hline \multicolumn{3}{c}{ Coho salmon } \\
\hline 2010 & $0.989(0.011)$ & $0.998(0.009)$ \\
2011 & $0.965(0.025)$ & $0.946(0.031)$ \\
2016 & $0.966(0.018)$ & $0.855(0.036)$ \\
\hline \multicolumn{3}{c}{ Chinook salmon } \\
\hline 2010 & $0.900(0.042)$ & $0.920(0.038)$ \\
\hline
\end{tabular}




\section{Discussion}

Juvenile salmon and steelhead moved quickly through Lake Scanewa, where mortality rates were low. This was particularly true for steelhead and coho salmon based on median travel times (from release location to arrival at Cowlitz Falls Dam) that were less than $1 \mathrm{~d}$ during most years, and average survival rates that exceeded 95 percent $(0.985$ for steelhead; 0.952 for coho salmon) for all study years. The lowest survival probability was 0.855 for coho salmon released in the Cispus River in 2016, which was the lowest flow year during our study period, and 79 percent of the average flow from 2007 to 2016. Chinook salmon had median travel times that were slightly slower (less than $2 \mathrm{~d}$ ), and average survival was 0.913 across all study years. There were no clear survival trends in the Cispus River compared to the Cowlitz River across the study years.

The transmitter failures we observed in 2016 likely resulted in negatively biased survival estimates, especially for coho salmon. The survival estimates may be underestimated because live fish could have moved downstream and passed detection sites without being detected, and thus would have been represented as mortalities during the survival analyses. Based on the proportion of failed tags in fish collected at the CFFF (9.4 percent for coho salmon and 2.2 percent for steelhead), the 2016 survival estimates for coho salmon were more likely to be underestimated compared to steelhead. The lowest survival estimate for coho salmon during our study was 0.855 for fish released into the Cispus River in 2016. The estimate for fish released into the Cowlitz River in 2016 was 0.966 , very similar to the estimate for that release site in 2011 (0.965). We believe that the overall tag failure rate (5.6 percent) is an underestimate of the actual failure rate because this type of failure had not been previously reported and therefore the staff at the CFFF was likely to have missed identifying fish with failures, especially early in the process of discovering and documenting the issue. This may be especially true for steelhead, as their migration timing and release dates were earlier than coho salmon, and therefore they arrived at the CFFF earlier.

The findings of high reservoir survival are not surprising given the small size of the reservoir and general lack of piscivorous fish. In 2011, we conducted a creel survey to determine catch rates in the trout fishery in Lake Scanewa (Liedtke and others, 2011). A total of 1,214 anglers were interviewed to determine species and number of fish caught. We found that most of the fish (96 percent) caught were rainbow trout, coho salmon, and Chinook salmon. With the exception of rainbow trout, Northern pikeminnow (Ptychocheilus oregonensis )(less than 1 percent of fish caught) were the only fish known to consume juvenile salmon and steelhead (Liedtke and others, 2011). We removed stomachs from angler-caught rainbow trout and examined contents to determine if stocked trout were piscivorous. In total, 2.3 percent of the stomachs examined contained fish, the majority (67 percent) of which was nonsalmonid species (Liedtke and others, 2011). However, juvenile coho salmon and Chinook salmon were found in some trout stomachs. Additional work to determine predation risk by stocked rainbow trout is ongoing and suggests that predation risk is minimal and predators are typically focused on smaller fish (parr and fry) than those that were tagged in our study. Given these findings and the results observed during 2010, 2011, and 2016, migration survival of smolt-sized fish is relatively high in Lake Scanewa. 
Juvenile salmon migration survival has been evaluated in numerous reservoirs throughout the Pacific Northwest. However, these reservoirs are generally large and have more complex fish communities than Lake Scanewa. For example, Detroit Reservoir is a 1,400 ha impoundment in the Willamette River Basin, Oregon. Outmigrating juvenile Chinook salmon were monitored using acoustic telemetry during 2012-14 and these studies showed that 57-86 percent of the fish that were released eventually moved downstream and were detected in the forebay of Detroit Dam (Beeman and others, 2014; Beeman and Adams, 2015; Kock and others, 2015). Median travel time from release at the head of the reservoir to arrival at the dam exceeded 1 week for most groups of fish, likely owing to the large size of the reservoir (Beeman and others, 2014; Beeman and Adams, 2015; Kock and others, 2015). Swift Reservoir is a 1,870 ha impoundment in the Upper Lewis River Basin, Washington. Telemetry studies in 2015 and 2016 found that 70-92 percent of the juvenile steelhead, 90-91 percent of the juvenile coho salmon, and 33-64 percent of the juvenile Chinook salmon that were tagged and released at the head of the reservoir eventually moved downstream and were detected in the forebay of Swift Dam (Reynolds and others, 2015; PacifiCorp and Public Utility District No. 1 of Cowlitz County, 2017). In some reservoirs, populations of piscivorous fish species exist in large numbers and pose significant threats to juvenile salmon and steelhead. Lookout Point Reservoir, located in the Willamette River Basin, supports abundant populations of northern pikeminnow, walleye (Sander vitreus), largemouth bass (Micropterus salmoides), black crappie (Pomoxis nigromaculatus), and white crappie (P. annularis). The predator community in Lookout Point Reservoir is believed to be substantial enough that reservoir passage efforts may need to be focused near the head of the reservoir, rather than at the dam, pending results from an ongoing evaluation of Chinook salmon fry survival (Kock and others, 2016). These examples show that Lake Scanewa is a small, simple impoundment in comparison to many other reservoirs throughout the Pacific Northwest. For these reasons, the migratory environment and predatory community in Lake Scanewa likely has fewer negative effects on juvenile salmon and steelhead populations compared to other reservoirs in the region.

\section{References Cited}

Beeman, J.W., and Adams, N.S., eds., 2015, In-reservoir behavior, dam passage, and downstream migration of juvenile Chinook salmon and juvenile steelhead from Detroit Reservoir and Dam to Portland, Oregon, February 2013-February 2014: U.S. Geological Survey Open-File Report 20151090, 92 p., https://doi.org/10.3133/ofr20151090.

Beeman, J.W., Hansel, H. C., Hansen, A.C., Evans, S.D., Haner, P.V., Hatton, T.W., Kofoot, E.E., Sprando, J.M., and Smith, C.D., 2014, Behavior and dam passage of juvenile Chinook salmon and juvenile steelhead at Detroit Reservoir and Dam, Oregon, March 2012-February 2013: U.S. Geological Survey Open-File Report 2014-1144, 62 p., https://doi.org/10.3133/ofr20141144.

Brandt, J.R., Monzyk, F.R., Romer, J.D., and Emig, R., 2016, Status and trends of predator species in Lookout Point Reservoir: Report by the Oregon Department of Fish and Wildlife to the U.S. Army Corps of Engineers, Portland, Oregon, 47 p.

Cormack, R.M., 1964, Estimates of survival from the sighting of marked animals: Biometrika, v. 51, nos. 3-4, p. 429-438.

Federal Energy Regulatory Commission, 1986, Order Issuing License for Project Number 2833-002 to the Public Utility District Number 1 of Lewis County, Washington, June 30, 1986, accessed March 2017, http://www.ecy.wa.gov/programs/wq/ferc/existingcerts/cowlitzfallslicenseorder.pdf .

Jolly, G.M., 1965, Explicit estimates from capture-recapture data with both death and immigrationstochastic model: Biometrika, v. 52, nos. 1-2, p. 225-248. 
Keefer, M.L., Taylor, G.A., Garletts, D.F., Helms, C.K., Gauthier, G.A., Pierce, T.M., and Caudill, C.C., 2012, Reservoir entrapment and dam passage mortality of juvenile Chinook salmon in the Middle Fork Willamette River: Ecology of Freshwater Fish, v. 21, p. 222-234.

Keefer, M.L., Taylor, G.A., Garletts, D.F., Helms, C.K., Gauthier, G.A., Pierce, T.M., and Caudill, C.C., 2013, High-head dams affect downstream fish passage timing and survival in the Middle Fork Willamette River: River Research and Applications, v. 29, p. 483-492.

Kock, T.J., Beeman, J.W., Hansen, A.C., Hansel, H.C., Hansen, G.S., Hatton, T.W., Kofoot, E.E., Sholtis, M.D., and Sprando, J.M., 2015, Behavior, passage, and downstream migration of juvenile Chinook salmon from Detroit Reservoir to Portland, Oregon, 2014-15: U.S. Geological Survey OpenFile Report 2015-1220, 30 p., https://doi.org/10.3133/ofr20151220.

Kock, T.J., Perry, R.W., Monzyk, F.R., Pope, A.C., and Plumb, J.M., 2016, Development of a study design and implementation plan to estimate juvenile salmon survival in Lookout Point Reservoir and other reservoirs of the Willamette Project, western Oregon: U.S. Geological Survey Open-File Report 2016-1211, 25 p., https://doi.org/10.3133/ofr20161211.

Laake, J.L., 2013, RMark-A R interface for analysis of capture-recapture data with MARK: AFSC Processed Report 2013-01, 25 p.

Liedtke, T.L., Beeman, J.W., and Gee, L.P., 2012, A standard operating procedure for the surgical implantation of transmitters in juvenile salmonids: U. S. Geological Survey Open-File Report 20121267, 50 p., https://pubs.er.usgs.gov/publication/ofr20121267.

Liedtke, T.L., Kock, T.J., Ekstrom, B.K., and Rondorf, D., 2009, Behavior and passage of juvenile salmonids during the evaluation of a fish screen at Cowlitz Falls Dam, Washington, 2008: Report by the U.S. Geological Survey to Tacoma Power, Tacoma, Washington, USA, Tacoma Power Report Series No. 2009-01.

Liedtke, T.L., Kock, T.J., Ekstrom, B.K., Tomka, R.G., and Rondorf, D.W., 2011, Evaluation of angler effort and harvest of rainbow trout (Onhorhynchus mykiss), Lake Scanewa, Washington, 2010: U.S. Geological Survey Open-File Report 2011-1178, 24 p., https://pubs.er.usgs.gov/publication/ofr20111178.

Muir, W.D., Smith, S.G., Williams, J.G., Hockersmith, E.E., and Skalski, J.R., 2001, Survival estimates for migrant yearling Chinook salmon and steelhead tagged with passive integrated transponders in the lower Snake and lower Columbia Rivers, 1993-1998: North American Journal of Fisheries Management, v. 21, p. 269-282.

Peven, C., Giorgi, A., Skalski, J., Langeslay, M., Grassell, A., Smith, S.G., Counihan, T., Perry, R., and Bickford, S., 2005, Guidelines and recommended protocols for conducting, analyzing, and reporting juvenile salmonid survival studies in the Columbia River Basin: Report to the U.S. Army Corps of Engineers, Portland, Oregon, 76 p.

PacifiCorp and Public Utility District No. 1 of Cowlitz County, 2017, Lewis River fish passage program 2016 annual report, $176 \mathrm{p}$.

R Core Team, 2013, A language and environment for statistical computing: R Foundation for Statistical Computing, Vienna, Austria.

Reynolds, E., Belcher, L., and Stevens, P., 2015, Swift reservoir floating surface collector juvenile salmon collection efficiency: 2015 Annual Report Memo, prepared by Cramer Fish Sciences (Gresham, OR). Prepared for Pacific Power (A Division of PacifiCorp).

Seber, G.A.F., 1965, A note on the multiple-recapture census: Biometrika, v. 52, nos. 1-2, p. 249-260. Serl, J.D., and Morrill, C.F., 2010, Summary report for the 1996 to 2009 seasonal operation of the Cowlitz Falls Fish Facility and related Upper Cowlitz River watershed anadromous fish reintroduction efforts: Washington Department of Fish and Wildlife Report to the U.S. Department of Energy, Bonneville Power Administration, Richland, Washington, 174 p. 
Skalski, J.R., Smith, S.G., Iwamoto, R.N., Williams, J.G., and Hoffmann, A., 1998, Use of passive integrated transponder tags to estimate survival of migrant juvenile salmonids in the Snake and Columbia Rivers: Canadian Journal of Fisheries and Aquatic Sciences, v. 55, p. 1484-1493.

Tipping, J.M., and Serl, J.D., 2000, Lake Scanewa creel census for 2000: 2000 Report, Washington Department of Fish and Wildlife, Olympia, Washington, USA.

White, G.C., and Burnham, K.P., 1999, Program MARK-Survival estimation from populations of marked animals: Bird Study, v. 46, no. sup1, p. S120-S139, https://doi.org/10.1080/00063659909477239 


\section{Chapter B. Dam Passage Survival of Juvenile Steelhead, Coho Salmon, and Chinook Salmon at Cowlitz Falls Dam, Cowlitz River, Washington, 2013-16}

\section{Introduction}

Dam passage survival evaluations are routinely conducted at hydropower and diversion dams to quantify survival rates of juvenile salmon and steelhead that pass through spillways, turbines, fish bypasses, and other routes (Normandeau Associates, 2010; Perry and others, 2016; Skalski and others, 2016). Results from these studies provide information that can be used by resource managers to understand population loss at a given project, and develop structural modifications, or operating procedures that increase passage through routes where survival is highest. At Cowlitz Falls Dam, dam passage survival was evaluated to aid in meeting regulatory requirements and to collect baseline data prior to some planned structural modifications. In general, route-specific survival at dams has been shown to be highest through surface routes such as spillways and fish bypasses, and lowest through the turbines (Muir and others, 2001; Normandeau Associates, 2010; Adams and others, 2014). Mortality that occurs at dams can result from direct effects as fish pass through a given route or from indirect effects downstream of the dam if fish are injured or disoriented and thus become more vulnerable to predation (Ferguson and others, 2006).

Dam passage survival is of interest at Cowlitz Falls Dam, on the upper Cowlitz River, Washington, where juvenile steelhead (Oncorhynchus mykiss), coho salmon (O. kisutch), Chinook salmon $(O$. tshawytscha), and cutthroat trout $(O$. clarkii clarkii) outmigrate annually. Fish passage primarily occurs through turbines, the fish collection facility, and the spillways. Cowlitz Falls Dam is a 70 megawatt hydroelectric dam constructed in the early 1990s. Power is generated using two Kaplanstyle turbines that can each accommodate about $149 \mathrm{~m}^{3} / \mathrm{s}$ of flow, so spill is not typically used until inflow exceeds $298 \mathrm{~m}^{3} / \mathrm{s}$. The fish collection facility at the dam consists of a series of entrances in the dam forebay and flume systems that convey fish to a sorting and processing facility. The facility is operated from April 15 to August 31 each year to capture steelhead, coho salmon, and cutthroat trout that primarily outmigrate from April through June, and Chinook salmon that outmigrate during JulyAugust. Spill can occur intermittently during April-June but does not typically occur during JulyAugust. Thus, the passage routes available to juvenile salmon at the dam vary with inflow and across the season; steelhead, coho salmon, and cutthroat trout typically pass through the fish facility, turbines, or spillways depending on flow conditions, but Chinook salmon passage is typically limited to the fish facility and turbines. 
An evaluation was conducted to estimate turbine passage survival of hatchery coho salmon through turbine Unit 2 in 2000 (Normandeau Associates and Skalski, 2001), but additional information is required to better understand route-specific survival through all possible routes and for multiple species. For the 2000 evaluation, juvenile coho salmon were obtained from the Cowlitz Salmon Hatchery and tagged with two uninflated balloon tags and a miniature radio transmitter. The balloon tags were injected with a catalyst to initiate inflation, fish were released at two locations within the turbine intake and were then recovered in the tailrace using boats to capture fish at the surface after the balloon tags inflated. Fish injury and mortality information was recorded at the time of recovery, and fish were then held for $48 \mathrm{~h}$, with survival reported $1 \mathrm{~h}$ post-passage and $48 \mathrm{~h}$ post-passage. In total, 245 tagged fish were released into the turbine intake with 1 and $48 \mathrm{~h}$ survival probabilities estimated to be 0.973 and 0.981, respectively (Normandeau Associates and Skalski, 2001). These results indicated that direct mortality from passage through turbine Unit 2 was low for coho salmon in 2000 . However, additional information is required to better understand if survival varies by species or across the outmigration season, and if indirect effects such as predation in the tailrace of the dam play a role in overall survival. We initiated a study to build on results from the 2000 evaluation and advance the stateof-knowledge on dam passage survival of juvenile salmon and steelhead at Cowlitz Falls Dam.

A multi-year study was conducted to estimate dam passage survival for juvenile steelhead, coho salmon, and Chinook salmon during 2013-16. Route-specific survival estimation requires large sample sizes because sufficient numbers of tagged fish must pass through each potential passage route to provide survival estimates that are reasonably precise. For this approach, a study design would likely include direct releases of a substantial number of fish into each passage route to insure that sample sizes in a given route were large enough to provide robust survival estimates. However, the direct release of fish into passage routes could lead to incorrect estimates of passage survival if fish are not distributed within the passage route as they would be when entering it volitionally from the dam forebay. Also, route-specific survival estimates may not be required if dam passage survival (the product of survival through all available passage routes) is high. Therefore, our study was designed as a pilot-level evaluation to investigate dam passage survival at Cowlitz Falls Dam and determine if further evaluation was required. If these dam passage survival estimates were lower than desired or were a concern for resource managers, future evaluations could be developed to evaluate route-specific passage survival at the dam. This pilot approach involved releasing fish upstream of the dam throughout the outmigration period and allowing them to pass the dam volitionally. Estimated survival was then compared to the survival of fish released downstream of the dam, at the downstream margin of the tailrace. This approached allowed us to estimate dam passage survival that included mortality that occurred within a given passage route and in the tailrace of the dam. 


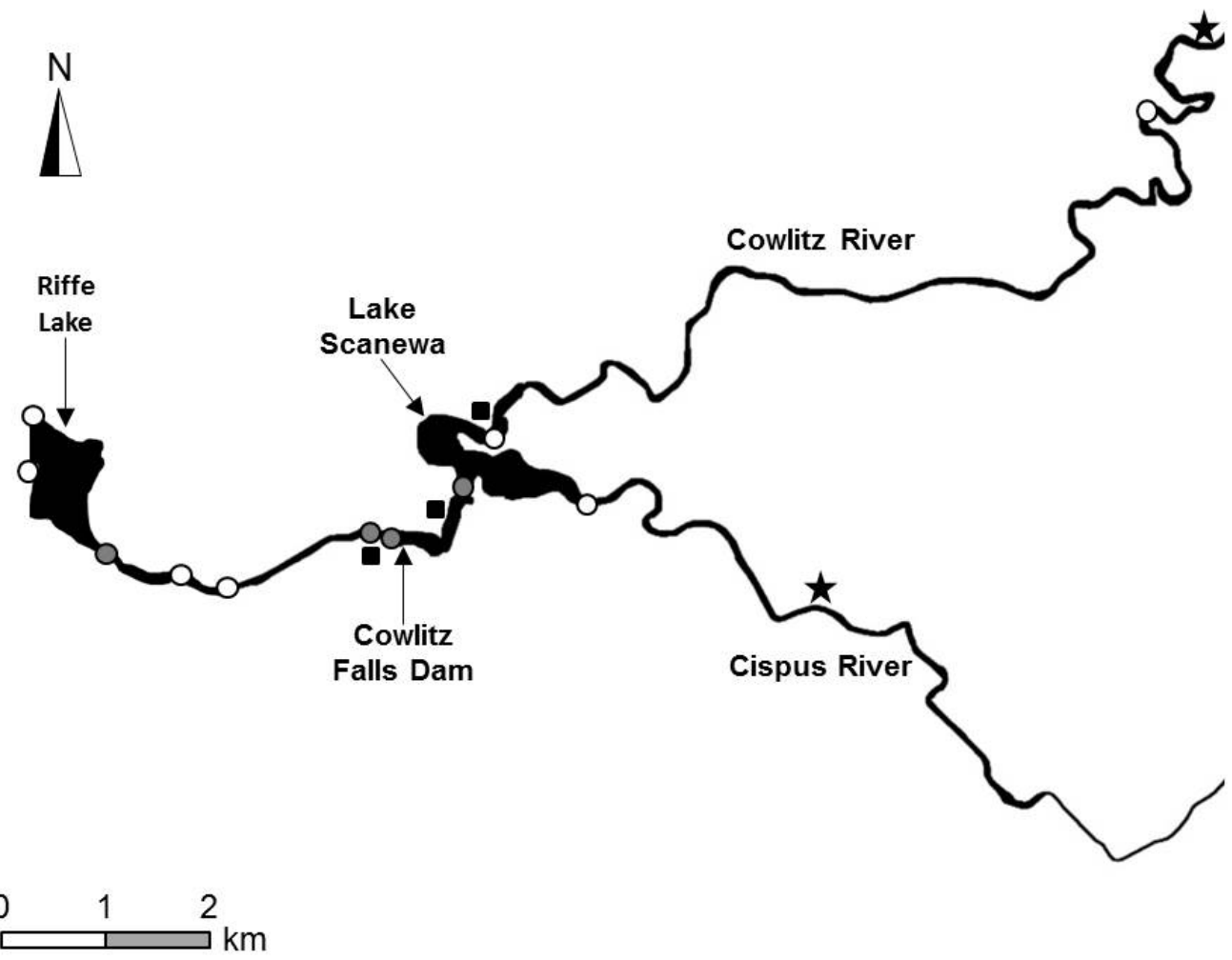

Figure B1. Schematic map of the upper Cowlitz River Basin showing Cowlitz Falls Dam, Lake Scanewa, and the Cowlitz and Cispus Rivers, Washington. Locations of fixed telemetry monitoring sites used to assess dam passage survival during 2013-16 also are shown. Fixed telemetry sites used during every study year are identified by solid circles and the location of fixed telemetry sites that were present during some study years are identified by open circles. The locations where tagged fish were released during 2013-15 are shown as solid squares. The release locations used upstream of the dam in 2016 are shown as stars (combined with the tailrace release site, shown as a square). 


\section{Methods}

\section{Fish Tagging and Release}

Fish were collected for tagging at the Cowlitz Falls Fish Facility (CFFF). Tagging methods and the process of identifying the target release periods for each study species were described in section, "Tagging and Release" of Chapter A of this report. Chinook salmon were evaluated during 2013-14, steelhead and coho salmon were evaluated during 2015-16, and the transmitter model used varied among years (table B1). Tagged fish were released at three sites during the study. The Lake Scanewa release sites were located at the Lewis County Public Utility District boat launch, $1.2 \mathrm{rkm}$ upstream of the dam and at the Cowlitz Falls Day Use Park, $3.6 \mathrm{rkm}$ upstream of the dam (fig. B1). The tailrace release site was located $0.3 \mathrm{rkm}$ downstream of the dam (fig. B1). Tailrace releases were timed to match the expected passage time of reservoir fish. In 2016, we evaluated reservoir passage survival and dam passage survival jointly so the Cowlitz River and Cispus River release sites described in section, "Monitoring Array" of Chapter A of this report were used along with the tailrace release site (fig. B1).

Table B1. Summary of radio transmitters, including model, weight, and operating life used to monitor juvenile steelhead, coho salmon, and Chinook salmon collected and tagged at Cowlitz Falls Fish Facility, Washington, 2013-16.

\begin{tabular}{clccc}
\hline Year & \multicolumn{1}{c}{ Species } & Transmitter model & Weight in air (g) & $\begin{array}{c}\text { Expected operating } \\
\text { life (d) }\end{array}$ \\
\hline 2013 & Chinook salmon & NTQ-2 & 0.31 & 33 \\
2014 & Chinook salmon & NTC-M-1 & 0.37 & 11 \\
2015 & Steelhead, coho salmon & NTC-M-2 & 0.43 & 18 \\
2016 & Steelhead, coho salmon & NTQ-2 & 0.31 & 27 \\
\hline
\end{tabular}

Monitoring Array

Aerial and underwater monitoring sites were used to document movements of fish throughout the study area. These sites were located in Lake Scanewa, in the forebay of the dam, and downstream of the dam (fig. B1). Aerial monitoring sites in Lake Scanewa were established in the Cowlitz arm of the reservoir (19.7 and 3.9 rkm upstream of Cowlitz Falls Dam), in the Cispus arm of the reservoir (3.4 rkm upstream of the dam), and downstream of the confluence of the two rivers (1.3 rkm upstream of the dam). Combinations of aerial and underwater arrays were established on the dam. The aerial arrays detected fish as they approached the dam and the underwater arrays provided fine-scale information on near-dam behavior, including documenting route-of-passage. Aerial sites located downstream of the dam monitored fish that passed the project and fish released into the tailrace. These sites were located in the dam's tailrace ( 0.2 and 0.3 rkm downstream of Cowlitz Falls Dam) and near the head of Riffe Lake $(2.8,3.5,4.7$, and $7.1 \mathrm{rkm}$ [two sites at this location] downstream of the dam; fig B1). 


\section{Data Analysis}

A paired release-recovery study design (Muir and others, 2001; Skalski and others, 2002, 2011) was used to estimate dam passage survival at Cowlitz Falls Dam. This design uses groups of fish released at two locations - one located upstream of the dam (treatment fish) and the other located downstream of the dam (control fish). Fish that moved downstream and passed the dam were monitored through a series of reaches to estimate their survival. Similarly, fish released downstream of the dam were monitored as they moved through the same reaches and their survival was estimated (fig. B2). Dam passage survival was then expressed as the ratio of the survival of the treatment fish and the control fish (fig. B2).

For this study, fish released upstream of Cowlitz Falls Dam were considered for analysis if they passed the dam. Fish that were collected at the fish facility or that remained upstream of the dam were excluded from analysis. Fish released downstream of the dam were included in the analysis as control fish. The downstream release site was located at the downstream margin of the dam tailrace $(0.3 \mathrm{rkm}$ downstream of the dam), which allowed the estimate of dam passage survival to include mortality that occurred to that point in the tailrace.

Detection records were queried to create five-digit capture histories that summarized detection information for each tagged fish. Capture histories used two digits ( 1 or 0$)$ to describe whether or not fish were known to be present at specific fixed sites within the study area. For the dam passage survival analysis, the five digits included in capture histories represented fixed sites located at the dam and at increasing distances downstream of the dam. Specifically, the first digit represented passage at Cowlitz Falls Dam; the second digit represented release at the downstream end of the tailrace or detection on a fixed site at that location ( $2.8 \mathrm{rkm}$ downstream of the dam); the third digit represented detection on a fixed site located $3.5 \mathrm{rkm}$ downstream of the dam; the fourth digit represented detection on a fixed site located $4.7 \mathrm{rkm}$ downstream of the dam; and the fifth digit represented detection on a fixed site located $7.1 \mathrm{rkm}$ downstream of the dam. A tagged fish was assigned a " 0 " if it was not detected at a given site and a " 1 if it was detected at that site. An example capture history of "11100" would describe a fish that passed the dam (1), and was detected at the fixed sites located $2.8 \mathrm{rkm}$ (1) and $3.5 \mathrm{rkm}(1)$ downstream of the dam, but not at the fixed sites at $4.7 \mathrm{rkm}(0)$ or $7.1 \mathrm{rkm}(0)$ downstream of the dam. 


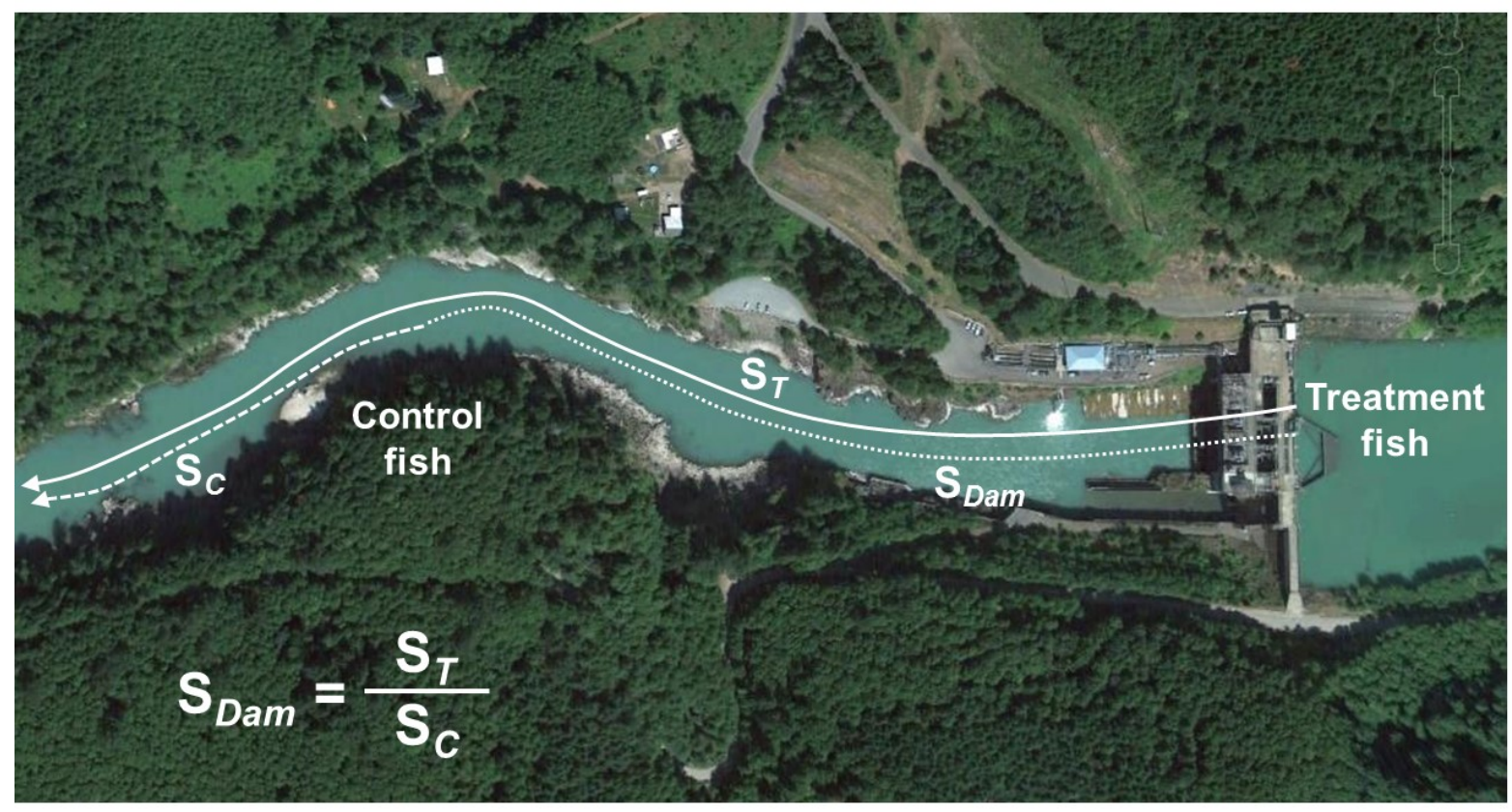

Figure B2. Image of Cowlitz Falls Dam, Washington, with overlays showing how survival was estimated for treatment fish $\left(S_{T}\right)$, control fish $\left(S_{C}\right)$, and for dam passage survival $\left(S_{D a m}\right)$.

The paired release-recovery study design includes nine assumptions described by Skalski and others (2002). There include:

1. Tagged individuals are a representative sample from the population of interest.

2. Survival and capture probabilities are not affected by tagging or sampling.

All sampling events are instantaneous.

3. The fate of each tagged individual is independent of the fate of all others.

4. All tagged individuals alive at a sampling location have the same probability of downstream survival.

5. All tagged individuals alive at a sampling location have the same probability of being detected.

6. All tags are correctly identified and the status of the individual (alive or dead) is correctly assessed.

7. Survival in the lower river segments is conditionally independent of survival in the upper river segments.

8. Release groups experience the same survival probability in the lower river segments. 
A critical part of conducting a telemetry-based smolt survival study is to ensure that negative or positive bias of the survival estimates is minimized. Negative bias in survival estimates can result from live fish moving through the study area with transmitters that are no longer functioning. Therefore, understanding the expected operating life of the transmitters in our study was critical. Using the procedures described in Chapter A of this report, we conducted laboratory evaluations to determine the observed operating life of each transmitter model used in our evaluations. A potential source of positive bias in survival estimates is the detection of a dead fish carrying an active transmitter (Peven and others, 2005). It is possible for tagged dead fish to drift downstream and be detected by the monitoring array, making it difficult to distinguish it from a live fish moving downstream. A common method for testing this assumption is to tag euthanized fish, release them into the study area with live study fish, and determine whether they are detected at downstream monitoring sites. Euthanized juvenile steelhead, coho salmon, and Chinook salmon were tagged and released at the same times and locations as study fish in order to evaluate this assumption.

\section{Results}

\section{Tagging and Release}

A total of 2,512 juvenile steelhead, coho salmon, and Chinook salmon were radio-tagged and released to evaluate dam passage survival at the Cowlitz Falls project during 2013-16. A larger proportion of the tagged fish (1,779 fish; 70.8 percent) were released into Lake Scanewa than into the dam's tailrace (733 fish; 29.2 percent; tables B2 through B5). Thirty-eight of the tagged fish (1.5 percent) were euthanized prior to their release into the tailrace to evaluate the downstream drift patterns of dead fish entering the Cowlitz Falls dam tailrace. The tagged fish population comprised 892 juvenile steelhead (35.5 percent), 644 juvenile coho salmon (25.6 percent), and 976 juvenile Chinook salmon (38.9 percent; tables B2-B5).

Table B2. Total number of radio-tagged juvenile Chinook salmon released into Lake Scanewa and the Cowlitz Falls Dam tailrace, Washington, to assess dam passage survival, 2013.

[Numbers in parentheses are tagged fish that were euthanized prior to release to determine downstream drift patterns of dead fish]

\begin{tabular}{lccc}
\hline \multirow{2}{*}{ Month } & \multirow{2}{*}{ Week } & \multicolumn{2}{c}{ Chinook salmon } \\
\cline { 3 - 4 } & & Reservoir & Tailrace \\
\hline July & 2 & 45 & $15(2)$ \\
July & 3 & 90 & $30(4)$ \\
July & 4 & 45 & 15 \\
July & 5 & 31 & $0(2)$ \\
August & 1 & 14 & 15 \\
August & 2 & 45 & 15 \\
August & 3 & 30 & $8(2)$ \\
\multicolumn{2}{c}{ Total $=$} & 300 & $98(10)$ \\
\hline
\end{tabular}


Table B3. Total number of radio-tagged juvenile Chinook salmon released into Lake Scanewa and the Cowlitz Falls Dam tailrace, Washington, to assess dam passage survival, 2014.

[Numbers in parentheses are tagged fish that were euthanized prior to release to determine downstream drift patterns of dead fish]

\begin{tabular}{|c|c|c|c|}
\hline \multirow{2}{*}{ Month } & \multirow{2}{*}{ Week } & \multicolumn{2}{|c|}{ Chinook salmon } \\
\hline & & Reservoir & Tailrace \\
\hline July & 3 & 55 & $24(2)$ \\
\hline July & 4 & 59 & $24(2)$ \\
\hline July & 5 & 76 & $24(2)$ \\
\hline August & 2 & 107 & $24(2)$ \\
\hline August & 3 & 124 & 43 \\
\hline \multicolumn{2}{|c|}{ Total $=$} & 421 & $139(8)$ \\
\hline
\end{tabular}

Table B4. Total number of radio-tagged juvenile steelhead and coho salmon released into Lake Scanewa and the Cowlitz Falls Dam tailrace, Washington, to assess dam passage survival, 2015.

[Numbers in parentheses are tagged fish that were euthanized prior to release to determine downstream drift patterns of dead fish]

\begin{tabular}{llrllc}
\hline \multirow{2}{*}{ Month } & \multirow{2}{*}{ Week } & \multicolumn{2}{c}{ Steelhead } & \multicolumn{2}{c}{ Coho salmon } \\
\cline { 3 - 6 } & & Reservoir & Tailrace & Reservoir & Tailrace \\
\hline April & 4 & 34 & 27 & & \\
April & 5 & 63 & $29(2)$ & & \\
May & 2 & 110 & 41 & 20 & 15 \\
May & 3 & 83 & $39(2)$ & 37 & 20 \\
May & 4 & 30 & $30(2)$ & 15 & $7(2)$ \\
May & 5 & & & 25 & 10 \\
June & 2 & & & 90 & $35(2)$ \\
June & 3 & & & 81 & $18(2)$ \\
\multicolumn{2}{c}{ Total $=$} & 320 & $166(6)$ & 268 & $105(6)$ \\
\hline
\end{tabular}

Table B5. Total number of radio-tagged juvenile steelhead and coho salmon released into Lake Scanewa and the Cowlitz Falls Dam tailrace to assess dam passage survival, 2016.

[Numbers in parentheses are tagged fish that were euthanized prior to release to determine downstream drift patterns of dead fish]

\begin{tabular}{lcclll}
\hline \multirow{2}{*}{ Month } & \multirow{2}{*}{ Week } & \multicolumn{2}{c}{ Steelhead } & \multicolumn{2}{c}{ Coho salmon } \\
\cline { 3 - 6 } & & Reservoir & Tailrace & Reservoir & Tailrace \\
\hline April & 5 & 48 & 23 & & \\
May & 1 & 52 & $25(2)$ & & \\
May & 2 & 52 & 28 & & \\
May & 3 & 40 & $28(2)$ & 20 & 14 \\
May & 4 & 36 & $22(2)$ & 22 & 18 \\
June & 1 & 29 & 11 & 26 & $18(2)$ \\
June & 2 & & & 18 & \\
June & 5 & & & 127 & \\
\multicolumn{2}{c}{ Total $=$} & 257 & $137(6)$ & 213 & $50(2)$ \\
\hline
\end{tabular}




\section{River Conditions}

Flow conditions were variable across the 4 years of study. See Chapter A of this report (fig. A2) for a detailed summary of annual flow conditions. Both 2013 and 2014 had average flow (April 1August 31) that was very similar to the 2007-16 10-year average for the same period. Both 2015 and 2016 were low flow years. The average flow in 2015 was only 45 percent of the 10 -year average flow, and was an extreme year for all river systems in the Pacific Northwest. The dramatically reduced flow caused elevated water temperatures in many river systems and likely had a similar effect in the Cowlitz River. In 2016, river flows increased, but were only 79 percent of the 10-year average flow.

\section{Downstream Movement}

Approximately one-half of the Chinook salmon released upstream of the dam moved downstream and passed the project, while more than one-third of the fish remained upstream and failed to pass the dam while their transmitters were operating. Fifty-two percent (374 fish; table B6) of the Chinook salmon released upstream of Cowlitz Falls Dam were detected downstream of the dam during 2013-14. The remaining fish either stayed upstream of the dam (37 percent), or were collected at the CFFF (11 percent; table B6). The median time from release to first detection in the dam tailrace, at the head of Riffe Lake, ranged from 3.4 to $8.7 \mathrm{~d}$ for Chinook salmon (fig. B3). The maximum elapsed time from release to first detection at the head of Riffe Lake was $44.9 \mathrm{~d}$ in 2013 and $16.6 \mathrm{~d}$ in 2014.

Most of the steelhead and coho salmon released upstream of the dam were collected at the CFFF, which resulted in low numbers of fish passing the dam. During 2015-16, 71 percent of the steelhead and 68 percent of the coho salmon moved downstream and were collected at the CFFF (table B6). During these years, 22 percent of the steelhead and 28 percent of the coho salmon remained upstream of the dam, and failed to pass the dam while their transmitters were operating (table B6). In total, only 40 of the steelhead ( 7 percent) and 18 of the coho salmon (4 percent) passed the dam during the study (table B6). The total number of steelhead and coho salmon that passed Cowlitz Falls Dam was too low to produce meaningful survival estimates. Therefore, we did not include these species in the survival analyses described later in this report.

Table B6. Fates of radio-tagged juvenile steelhead, coho salmon, and Chinook salmon released into Lake Scanewa to assess dam passage survival, 2013-16.

[Numbers in parentheses are percent of fish in each category. CFFF is the Cowlitz Falls Fish Facility]

\begin{tabular}{llcccc}
\hline Year & \multicolumn{1}{c}{ Species } & $\begin{array}{c}\text { Downstream of } \\
\text { Cowlitz Falls Dam }\end{array}$ & $\begin{array}{c}\text { Collected at } \\
\text { the CFFF }\end{array}$ & $\begin{array}{c}\text { Upstream of } \\
\text { Cowlitz Falls Dam }\end{array}$ & $\begin{array}{c}\text { Total } \\
\text { released }\end{array}$ \\
\hline 2013 & Chinook salmon & $144(48)$ & $33(11)$ & $123(41)$ & 300 \\
2014 & Chinook salmon & $230(55)$ & $50(12)$ & $141(33)$ & 421 \\
2015 & Steelhead & $7(2)$ & $226(71)$ & $87(27)$ & 320 \\
2015 & Coho salmon & $12(4)$ & $168(63)$ & $88(33)$ & 268 \\
2016 & Steelhead & $33(13)$ & $182(71)$ & $42(16)$ & 257 \\
2016 & Coho salmon & $6(3)$ & $159(75)$ & $48(23)$ & 213 \\
\hline
\end{tabular}




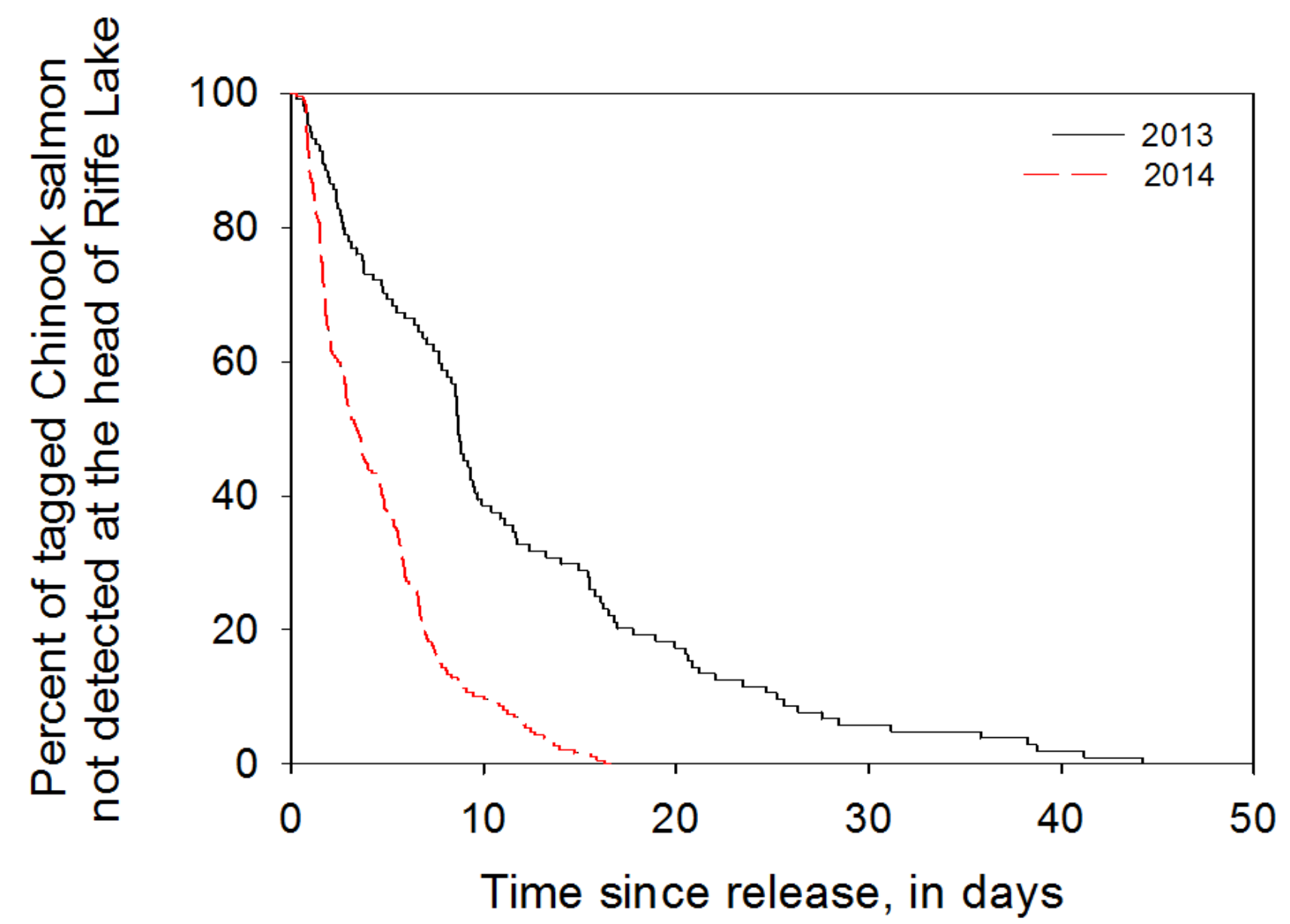

Figure B3. Percentage of tagged juvenile Chinook salmon that passed Cowlitz Falls Dam, Washington, that were not detected on fixed sites at the head of Riffe Lake as a function of time after release, 2013-14.

In 2016, as steelhead and coho salmon moved downstream and were re-collected at the CFFF, a transmitter failure issue was identified. Staff at the CFFF observed that some of the collected fish had obvious incisions and sutures (evidence that they had been surgically implanted with a radio transmitter) but did not have a radio transmitter antenna trailing along the lateral aspect of the fish, as is typical (appendix 1). When we examined these fish, and removed the transmitter, we discovered that the antenna had become separated from the main body of the transmitter. This type of transmitter failure had not been observed previously, in our Cowlitz River telemetry studies, or in any published account. The total number of radio-tagged steelhead and coho salmon collected at the CFFF in 2016 was 341, and 19 of these fish (5.6 percent) had transmitters with broken antennas (appendix 1). The tag failures were more common for coho salmon than for steelhead. There were 182 tagged steelhead collected at the CFFF, and four of these had broken antennas (2.2 percent). For coho salmon, 159 fish were collected, and 15 had broken antennas (9.4 percent). Fish were collected at the CFFF with broken antennas as early as $3 \mathrm{~d}$ after they were released into the reservoir, and as late as $27 \mathrm{~d}$. One fish was found without a trailing antenna within hours after tagging, as it was being transported to the reservoir for release. To better understand the rate of tag failure, we initiated a controlled laboratory study (appendix 1). In the laboratory tests, tag failures occurred from 4 to $38 \mathrm{~d}$ after tagging (appendix 1). 


\section{Dam Passage Survival}

The paired release-recovery study design used in this study is subject to nine assumptions described by Skalski and others (2002). For the first assumption, study fish were randomly selected from the run-at-large that was collected at Cowlitz Falls Dam between the historical 5th and 95th percentiles of the run timing for each species (figs. B4-B5). We used a maximum tag burden (transmitter weight in grams divided by fish weight in grams) of 5 percent to limit potential tag effects on study fish as recommended by Liedtke and others (2012). In some cases, this fish selection criterion limited our ability to tag the smallest fish in the population (figs. B4-B5).
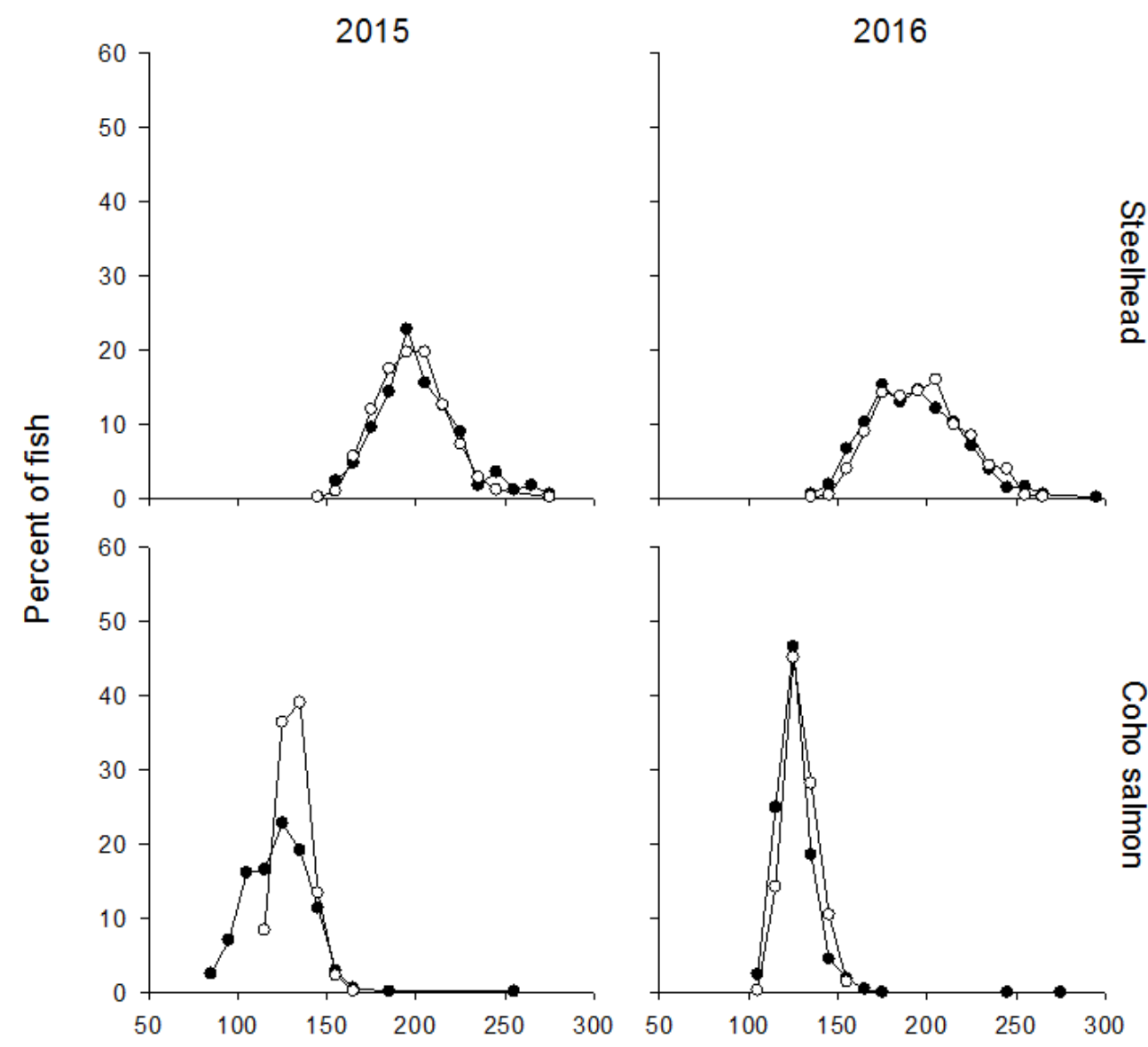

Fork length, in $\mathrm{mm}$

Figure B4. Size distributions of all juvenile steelhead and coho salmon collected at the Cowlitz Falls Fish Facility (solid circles), Washington, during 2015-2016, and those that were radio-tagged and released to estimate reservoir passage survival (open circles). 


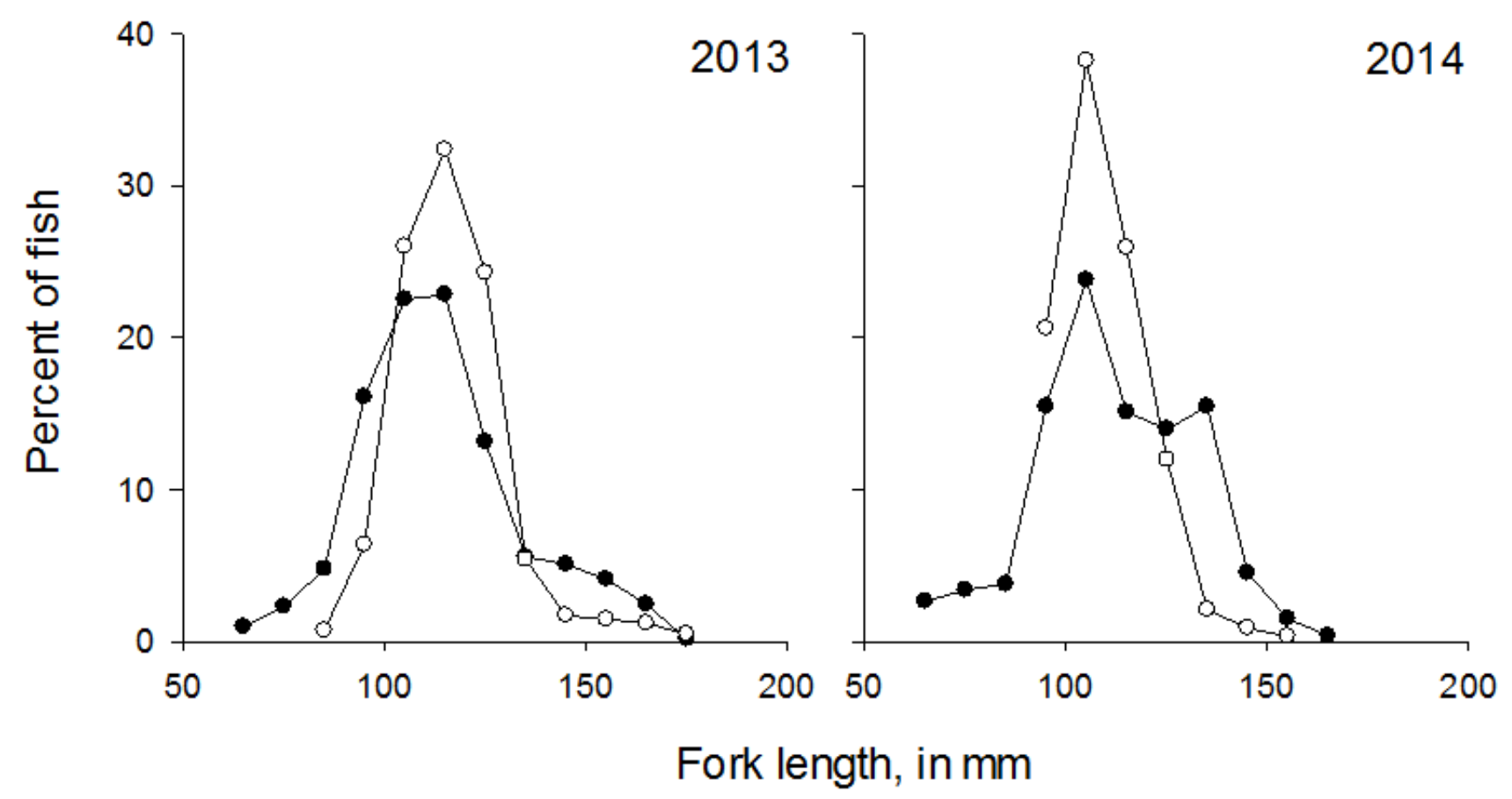

Figure B5. Size distributions of all juvenile Chinook salmon collected at the Cowlitz Falls Fish Facility (solid circles), Washington, during 2013-14, and those that were radio-tagged and released to estimate reservoir passage survival (open circles).

Our evaluations of transmitter life for each year of study suggest that premature tag failures were not likely to bias our survival estimates. Measuring transmitter life is part of evaluating model assumptions six and seven. Assumption seven requires that the status (alive or dead) of each fish is correctly assessed. Measuring tag actual tag life, not just expected tag life is critical for this assumption. For example, a live fish may carry a transmitter that stopped operating prior to the end of expected tag life, and could therefore be incorrectly assigned a fate of dead in the survival model. For assumption six, fish with failed tags would not have equal detection probabilities compared to functional tags. The 90th percentile of the operating life of radio transmitters were determined to be $51 \mathrm{~d}$ in 2013 , and $18 \mathrm{~d}$ in 2014 (fig. B6). In 2013, the earliest any transmitter stopped operating was $47.2 \mathrm{~d}$ after activation and the longest-lived transmitter stopped operating $79.2 \mathrm{~d}$ after activation. The shore test and longest-lived transmitters in 2014 were 19.9 and 22.9 d, respectively. Based on these results and the fact that most fish arrived in the tailrace of Cowlitz Falls Dam within $16 \mathrm{~d}$ of release (fig. B3), survival estimates are unlikely to be biased based on premature tag failures. 
Our release and monitoring of euthanized tagged fish suggest a low risk of the inappropriate assignment of the status (alive or dead) of study fish and support the assessment that model assumption seven was met. In total, 38 fish were tagged, euthanized, and released into the tailrace with live fish to determine if dead fish could drift downstream and be detected on monitoring sites. Most of the euthanized fish (30 fish, 79 percent) were detected in the tailrace of Cowlitz Falls Dam following release, but none of the euthanized fish were detected in Riffe Lake (table B7). Based on this information, we do not believe that downstream drift of dead fish resulted in biased estimates of dam passage survival during the study.

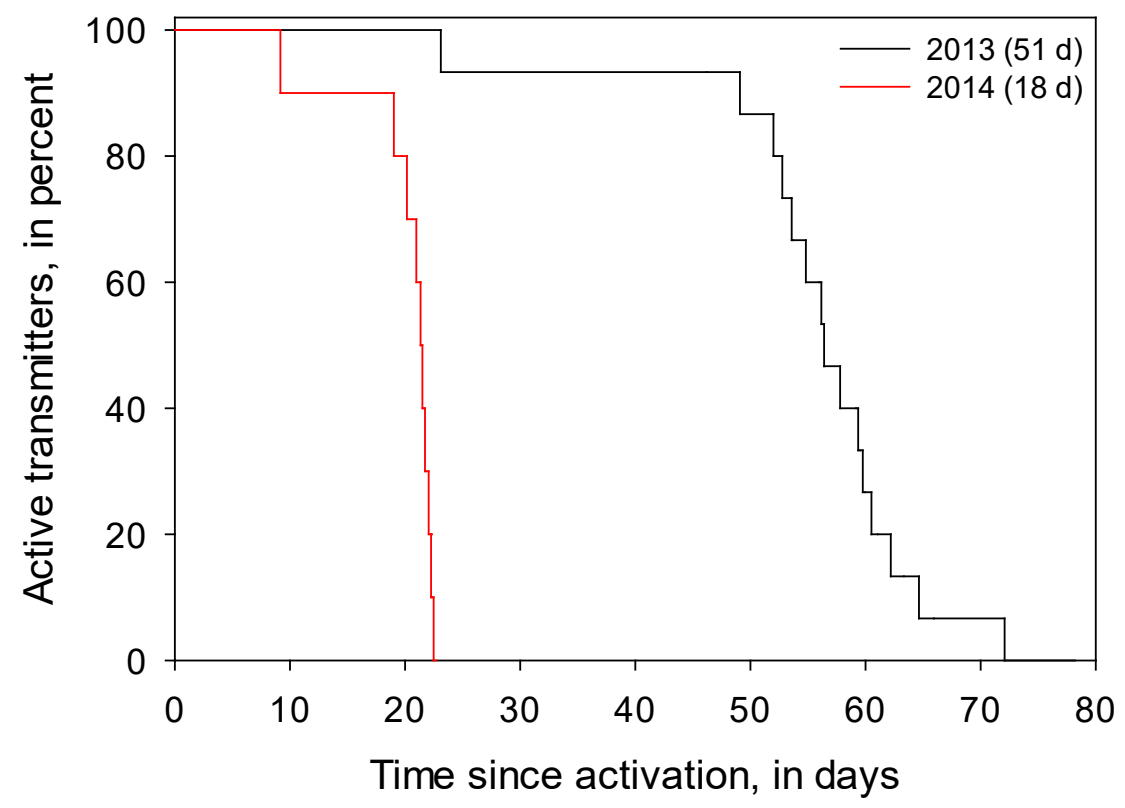

Figure B6. Operating life of radio transmitters used to evaluate dam passage survival at Cowlitz Falls Dam, Washington, 2013-14. The 90th percentile of the operating life of transmitters from each study year are shown in parentheses.

The remaining model assumptions were met through study design and execution procedures, or through data analyses. The second model assumption states that survival and capture probabilities are not affected by tagging or sampling. This assumption was met through the use of experienced taggers and effective fish handling and transport procedures. We have extensive experience tagging and releasing juvenile salmon with limited effects on performance (Liedtke and others, 2012). The third model assumption, that all sampling events are instantaneous, was met based on our monitoring array having capability of detecting tagged fish instantaneously. Assumption nine was met by comparing detection probabilities for individual releases. The remaining assumptions (assumptions four, five, six, and eight) are based on statistical independence and comparable detection probabilities for all tagged fish. During data analyses, we review individual fish detection histories and gain an understanding of fish movements in the study area. Through these analyses, and the knowledge that our study design was established to address model assumptions, we are confident that the all model assumptions were met. 
Table B7. Number of tagged steelhead, coho salmon, and Chinook salmon euthanized, released, and detected at Cowlitz Falls Dam, Washington, 2013-16.

\begin{tabular}{lccccc}
\hline \multicolumn{1}{c}{ Species } & Year & Not detected & $\begin{array}{c}\text { Detected in } \\
\text { tailrace of } \\
\text { Cowlitz Falls Dam }\end{array}$ & $\begin{array}{c}\text { Detected in } \\
\text { Riffe Lake }\end{array}$ & Total \\
\hline Chinook salmon & 2013 & 2 & 8 & 0 & 10 \\
Chinook salmon & 2014 & 1 & 7 & 0 & 8 \\
Steelhead & 2015 & 2 & 4 & 0 & 6 \\
Coho salmon & 2015 & 2 & 4 & 0 & 6 \\
Steelhead & 2016 & 0 & 6 & 0 & 6 \\
Coho salmon & 2016 & 1 & 1 & 0 & 2 \\
& Total & 8 & 30 & 0 & 38 \\
\hline
\end{tabular}

Survival probability estimates suggest that dam passage survival was high for juvenile Chinook salmon. Survival probabilities ranged from 0.828 to 0.861 for juvenile Chinook salmon (table B8). Survival in 2013 could have been as low as 0.729 and as high as 0.931 (95-percent confidence intervals). In 2014, the 95-percent confidence intervals were 0.813 and 0.909 . Relatively few juvenile steelhead and coho salmon passed Cowlitz Falls Dam in 2015 and 2016, precluding an accurate estimation of dam passage survival for those species. Of the steelhead released, only 40 (7 percent) passed the dam (table B6). For coho salmon, 18 total fish (4 percent) passed Cowlitz Falls Dam during the 2 years of evaluation (table B6).

Table B8. Estimates of survival probabilities for juvenile Chinook salmon that passed Cowlitz Falls Dam, Cowlitz River, Washington, 2013-14.

[Standard errors of survival probability estimates are in parentheses]

\begin{tabular}{cc}
\hline Year & Survival \\
\hline 2013 & $0.828(0.051)$ \\
2014 & $0.861(0.025)$ \\
\hline
\end{tabular}




\section{Discussion}

Information collected during 2013-14 yielded survival estimates for juvenile Chinook salmon, but abnormally high collection efficiencies during 2015-16 precluded estimation of dam passage survival for juvenile steelhead and coho salmon because few tagged fish passed the dam. This study was conceived as a first-step towards addressing the desire of resource managers to obtain route-specific dam passage survival information for multiple life stages (fry, parr, smolt, adult) of steelhead, coho salmon, and Chinook salmon that pass downstream through Cowlitz Falls Dam. Although technically possible, the collection of these data would be difficult and costly, because route-specific survival evaluations generally require large numbers of fish be tagged, and some life stages would be too small for tagging (fry) or difficult to collect (adults). Therefore, we proposed an initial multi-year study design to measure dam passage survival of smolt-sized fish as the first step in the process to evaluate dam passage survival. This approach used a pilot-level effort that would provide defensible estimates of dam passage survival, which would advance the state-of-knowledge on passage conditions at Cowlitz Falls Dam. Limited availability of passage routes at the dam also provided the possibility of estimating passage survival through the turbines, since spillways are used infrequently during spring months when steelhead and coho salmon are passing the dam, and rarely during summer months when Chinook salmon are passing. Our paired-release study design was based on collection efficiencies at the CFFF during 1996-2012, which averaged 46 percent for juvenile steelhead, 30 percent for juvenile coho salmon, and 22 percent for juvenile Chinook salmon (John Serl, Washington Department of Fish and Wildlife, oral commun., 2017). Using these expected capture rates, we developed sample sizes for tagged fish that would be released upstream of Cowlitz Falls Dam, and allowed to move downstream and pass the dam volitionally. This approach worked well in 2013 and 2014 with juvenile Chinook salmon because capture efficiencies at the CFFF were lower than expected, which increased the number of fish available to pass downstream through the dam. However, collection efficiencies of steelhead and coho salmon were exceptionally high in 2015-16 (steelhead average was 80 percent; coho salmon average was 88 percent, John Serl, Washington Department of Fish and Wildlife, oral commun., 2017) so very few fish passed the dam. The high collection rates these years were likely due to the atypically low flows observed. The flows in 2015 were extremely low (45 percent of the 10-year average), and flows in 2016 were higher, but still only 79 percent of the 10-year average. The high CFFF collection rates resulted in sample sizes that were too low to provide meaningful estimates of dam passage survival during those years. The capture efficiencies for different species of salmonids, especially relative to flow conditions, will be an important consideration in future study designs at Cowlitz Falls Dam. 
Transmitter failures observed in 2016 may have contributed to the low numbers of steelhead and coho salmon detected passing the dam. Fish with failed transmitters could have passed the dam without being detected. Based on the proportion of failed tags in fish collected at the CFFF (9.4 percent for coho salmon and 2.2 percent for steelhead), the number of coho salmon passing the dam was more likely to be underestimated compared to steelhead. The proportion of steelhead that passed the dam was higher in 2016 (13 percent) than in 2015 ( 2 percent), so tag failures did not appear to be a significant factor for steelhead. For coho salmon, the proportion of fish that passed the dam each year was similar-12 fish in 2015 (4 percent of tagged fish) and 6 fish in 2016 ( 3 percent of tagged fish), suggesting a limited influence of tag failures. If we assume that 9.4 percent of the coho salmon that remained upstream of the dam in 2016 (48 fish) were affected by tag failures and may, therefore have passed the dam without being detected (assuming an unrealistic scenario of 0 percent collection efficiency), the total number of coho salmon available for a dam passage survival estimate in 2015-16 would have been 23 (12 fish in 2015, 6 known to have passed in 2016, and 5 estimated due to tag failures). This total sample size is still too low to provide meaningful estimates of dam passage survival for coho salmon, thus the tag failure may have contributed to, but does fully explain the low numbers of fish observed passing the dam.

Dam passage survival estimates for juvenile Chinook salmon in 2013 and 2014 suggest that passage mortality is higher for juvenile salmonids at Cowlitz Falls Dam than previously reported. Survival probability estimates were 0.828 in 2013 and 0.861 in 2014, which are substantially lower than the $48 \mathrm{~h}$ post-passage survival probability estimate $(0.981)$ reported by Normandeau Associates and Skalski (2001) for juvenile coho salmon passage through turbine unit 2 during an evaluation in 2000. This may be due, in part, to our paired-release approach. The 2000 study design included the direct release of tagged fish into the turbine intake followed by recovery of tagged fish in the dam's tailrace. This approach effectively measured the mortality associated with the passage event only. Our study design allowed tagged fish to volitionally pass the dam and move downstream into Riffe Lake. A second group of tagged fish was used as controls and was released about $0.3 \mathrm{rkm}$ downstream of the dam, at the downstream margin of the tailrace. This approach allowed us to estimate the cumulative passage survival of fish through the dam, and through the tailrace. Based on this approach, our results suggest that 14-17 percent of the Chinook salmon that passed through Cowlitz Falls Dam did not survive in 2013 and 2014, from the point of dam passage to the downstream margin of the tailrace. However, this mortality rate is negligible given the current situation for downstream passage in the Cowlitz River Basin. Previous studies have shown that juvenile salmon and steelhead become landlocked in Riffe Lake following passage at Cowlitz Falls Dam (Liedtke and others, 2009), and are effectively lost to the anadromous fish population. 
Dam passage survival has been shown to vary substantially at high-head dams with factors such as passage route, passage opening size, and discharge affecting survival. For example, at Detroit Dam on the North Santiam River, Oregon, direct spillway passage survival ranged from 81 to 84 percent when the spill gate had a 1.5-ft opening, but decreased to 64 to 67 percent when the opening was increased to 3.5-ft (Normandeau Associates, Inc., 2010). Passage survival through a regulating outlet at Detroit Dam was evaluated at two conditions-1-ft opening at $460 \mathrm{ft}^{3} / \mathrm{s}$ and 5 - $\mathrm{ft}_{\text {opening }}$ at $1,800 \mathrm{ft}^{3} / \mathrm{s}$. The researchers found that survival was 72 percent in the former condition and 94 percent in the latter (Normandeau Associates, Inc., 2010). Finally, survival through the powerhouse at Detroit Dam was 54 percent (Normandeau Associates, Inc., 2010). The variability in observed survival among routes at a single high-head dam illustrates the complexity of dam passage survival, and underlines the need for a large well-designed study to collect data that accurately describe passage survival throughout a fish

migration season. The data collected at Cowlitz Falls Dam during the pilot-level evaluations of 2013-16 can be used to develop more rigorous study designs in the future.

\section{References Cited}

Adams, N.S., Plumb, J.M., Perry, R.W., and Rondorf, D.W., 2014, Performance of a surface bypass structure to enhance juvenile steelhead passage and survival at Lower Granite Dam, Washington. North American Journal of Fisheries Management, v. 34, p. 576-594.

Ferguson, J.W., Absolon, R.F., Carlson, T.J., and Sandford, B.P., 2006, Evidence of delayed mortality on juvenile Pacific salmon passing through turbines at Columbia River dams: Transactions of the American Fisheries Society, v. 135, p. 139-150.

Liedtke, T.L., Beeman, J.W., and Gee, L.P., 2012, A standard operating procedure for the surgical implantation of transmitters in juvenile salmonids: U.S. Geological Survey Open-File Report 20121267, 50 p., https://pubs.er.usgs.gov/publication/ofr20121267.

Liedtke, T.L., Kock, T.J., Ekstrom, B.K., and Rondorf, D.W., 2009, Behavior and passage of juvenile salmonids during the evaluation of a fish screen at Cowlitz Falls Dam, Washington, 2008: Report by the U.S. Geological Survey to Tacoma Power, Tacoma, Washington, USA, Tacoma Power Report Series No. 2009-01.

Normandeau Associates, Inc., 2010, Estimates of direct survival and injury of rainbow trout passing spillway, turbine and regulating outlet and turbine at Detroit Dam, Oregon: Report for the U.S. Army Corps of Engineers, Portland, Oregon, 182 p.

Normandeau Associates, Inc., and Skalski, J.R., 2001, Survival and condition of coho salmon smolts passed through the Cowlitz Falls Project, Cowlitz River, Washington: Report for the Public Utility District \#1 of Lewis County, Randle, Washington, 42 p.

Muir, W.D., Smith, S.G., Williams, J.G., Hockersmith, E.E., and Skalski, J.R., 2001, Survival estimates for migrant yearling Chinook salmon and steelhead tagged with passive integrated transponders in the lower Snake and lower Columbia Rivers, 1993-1998: North American Journal of Fisheries Management, v. 21, p. 269-282, https://doi.org/10.1577/15488675(2001)021<0269:SEFMYC >2.0.CO;2.

Perry, R.W., Kock, T.J., Courter, I.I., Garrison, T.M., Hubble, J.D., and Child, D.B, 2016, Dam operations affect route-specific passage and survival of juvenile Chinook salmon at a main-stem diversion dam: River Research and Applications, v. 32, p. 2009-2019.

Peven, C., Giorgi, A., Skalski, J., Langeslay, M., Grassell, A., Smith, S.G., Counihan, T., Perry, R., and Bickford, S., 2005, Guidelines and recommended protocols for conducting, analyzing, and reporting juvenile salmonid survival studies in the Columbia River Basin: Report to the U.S. Army Corps of Engineers, Portland District, Portland, Oregon. 
Skalski, J.R., Lady, J., Townsend, R., Giorgi, A.E., Stevenson, J.R., Peven, C.M., and McDonald, R.D., 2011, Estimating in-river survival of migrating salmonid smolts using radiotelemetry: Canadian Journal of Fisheries and Aquatic Sciences, v. 58, p. 1987-1997.

Skalski, J.R., Townsend, R., Lady, J., Giorgi, A.E., Stevenson, J.R., and McDonald, R.D., 2002, Estimating route-specific passage and survival probabilities at a hydroelectric project from smolt radiotelemetry studies: Canadian Journal of Fisheries and Aquatic Sciences, v. 59, p. 1385-1392. Skalski, J.R., Weiland, M.A., Ham, K.D., Ploskey, G.R., McMichael, G.A., Colotelo, A.H., Carlson, T.J., Woodley, C.M., Eppard, M.B., and Hockersmith, E.E., 2016, Status after 5 years of survival compliance testing in the Federal Columbia River Power Systems (FCRPS): North American Journal of Fisheries Management, v. 36, p. 720-730. 


\title{
Appendix 1. Summary of Radio Transmitter Failures Associated with the 2016 Cowlitz River Evaluations
}

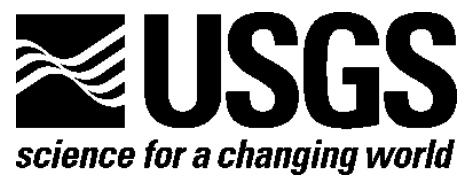

\author{
To: $\quad$ Mike Kohn, Lewis County Public Utility District \\ Gonzalo Mendez, Portland General Electric \\ All other interested parties \\ From: $\quad$ Tobias J. Kock \\ Theresa L. Liedtke \\ Subject: Laboratory Evaluation to Determine Antenna Failure Rates of \\ Lotek NTQ-2 Radio Transmitters, 2016
}

Date: $\quad$ October 24, 2016

\section{Background}

A previously unobserved transmitter failure issue was identified with Lotek NTQ-2 radio transmitters during field studies on the Cowlitz River, Washington, and Deschutes River, Oregon, in 2016. Reservoir survival and dam passage survival of juvenile steelhead and coho salmon were evaluated on the upper Cowlitz River during April-July 2016. For this study, juvenile salmon and steelhead were collected at Cowlitz Falls Dam, where they were radio- tagged, and these fish were then transported to the upper bounds of Lake Scanewa where they were released. A portion of the released radio-tagged fish eventually moved downstream and was recollected at Cowlitz Falls Dam. In total, 471 tagged fish were released upstream of Cowlitz Falls Dam in 2016 and 341 (72\%) of the tagged fish were recollected. Staff at the Cowlitz Falls Fish Facility observed that some of the collected fish had obvious incisions and sutures (evidence that they had been surgically implanted with a radio transmitter) but did not have a radio transmitter antenna trailing along the lateral aspect of the fish, as is typical. These fish were held for examination and the transmitters were later removed. We discovered that the antenna was broken and no longer attached to the body of the transmitter (fig. 1-1). Overall, we found that 19 of the $341(5.6 \%)$ tagged fish that were recollected at the fish facility had transmitters with broken antennas. Similar issues were identified in a study on the Deschutes River but the rate of antenna failures was unclear because fish were not recovered following release (oral communication, Gonzalo Mendez, Portland General Electric). The antenna failures noted in the Portland General Electric study occurred within about 24 hours of tagging, while fish recovering from tagging were held in containers, prior to release. 
In studies using telemetry to estimate survival, antenna failure will result in negatively biased survival estimates because live fish can move downstream and pass detection gates without being detected. Therefore, it is critical to understand antenna failure rates to make attempts to account for this issue when estimating survival. To accomplish this, we conducted a laboratory evaluation at the Columbia River Research Laboratory in Cook, Washington during July-September 2016. This document describes that evaluation.

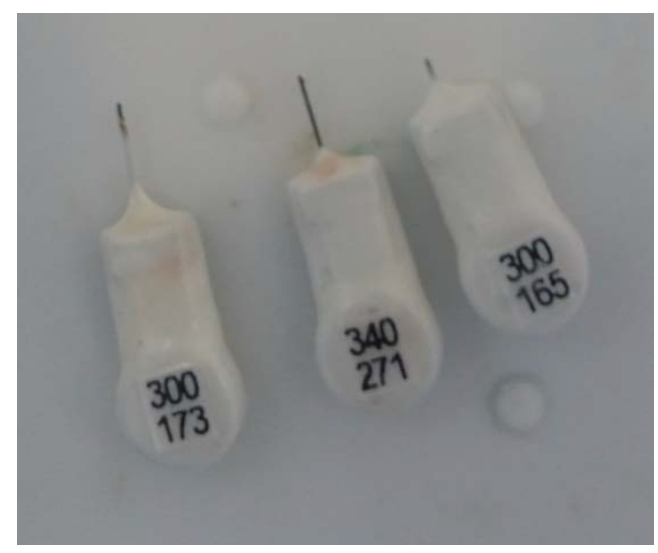

Figure 1-1. Photograph of three Lotek NTQ-2 radio transmitters recovered from tagged fish recollected at the Cowlitz Falls Fish Facility during 2016. The transmitter antenna broke and was lost during the period between when fish were released and when they were recollected.

\section{Methods}

A total of 102 transmitters were available for testing; 80 were provided by Lewis County PUD (LCPUD) and 22 were provided by Portland General Electric (PGE). All transmitters used in the test were from the tag orders and production lots that were used to conduct the field studies where the antenna failures had been observed. Tagging occurred on two days, July 19 and July 20, 2016. Transmitters were surgically implanted into juvenile Chinook salmon using methods described in Liedtke and others, 2012, by a single, experienced tagger The average fork length of study fish was $153.0 \mathrm{~mm}$ (standard deviation $=22.3$ ) and the average weight was $41.2 \mathrm{~g}$ ( standard deviation $=17.7 \mathrm{~g}$ ). We tested antenna failure rates under two temperature regimes hereafter referred to as "warm" and "cool". We chose this approach to determine if water temperature affected antenna failure rates and the temperature regimes were based on conditions observed in the field. The cool regime ranged from 8.0 to $12.0{ }^{\circ} \mathrm{C}$ which was similar to water temperatures observed during the Cowlitz River and Deschutes River spring studies in 2016 (fig. 2). The warm regime ranged from 12.0 to $16.0{ }^{\circ} \mathrm{C}$ which was similar to water temperatures commonly observed during summer months on the Cowlitz River (fig. 2). 
Tagged fish were held in four fiberglass tanks that each received temperature-controlled passthrough flow. Two tanks were maintained at cool regime temperatures and two tanks were maintained at warm regime temperatures (fig. 1-2). Each tank held 25 or 26 tagged fish so each temperature regime included a total of 51 tagged fish (table 1-1). Each tank was examined daily to identify when antenna failure occurred. This was accomplished by examining the bottom of each tank for transmitter antennas. When this occurred, the tagged fish with a missing antenna was carefully identified (by visual exam) and gently removed from the tank, then euthanized so the transmitter could be recovered. One tank was monitored with a telemetry receiver to determine when battery failure occurred which signified the end of the test.

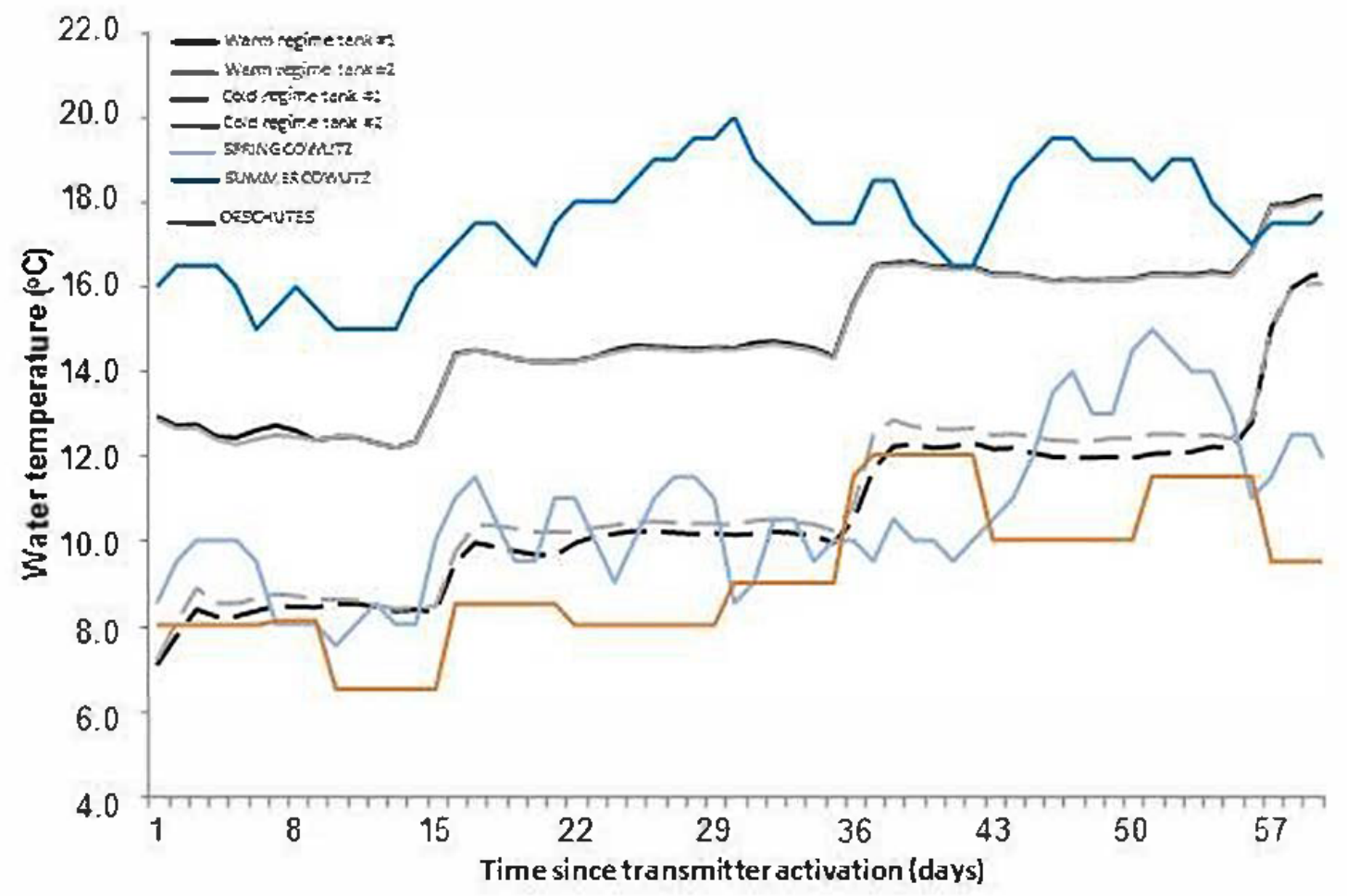

Figure 1-2. Water temperature data from the Cowlitz River during spring and summer months, from the Deschutes River during spring months, and from fiberglass tanks where antenna failure rates were measured during a laboratory study in 2016. 
Table 1-1. Number of tagged juvenile Chinook salmon in each fiberglass tank from a laboratory study to assess antenna failure in 2016.

[Data are presented for each frequency tested during the study and also included is the entity that provided transmitters for testing. Numbers of tags with failed antennas are shown in parentheses]

\begin{tabular}{|c|c|c|c|c|}
\hline \multirow{2}{*}{ Tank number } & \multicolumn{2}{|c|}{ LCPUD } & \multirow{2}{*}{$\begin{array}{c}\text { PGE } \\
150.890 \mathrm{mHz}\end{array}$} & \multirow{2}{*}{ Total } \\
\hline & $150.300 \mathrm{mHz}$ & $150.340 \mathrm{mHz}$ & & \\
\hline \multicolumn{5}{|c|}{ Cool regime } \\
\hline 1 & $12(0)$ & $8(0)$ & $5(0)$ & $25(0)$ \\
\hline 2 & $13(0)$ & $7(0)$ & $6(0)$ & $26(0)$ \\
\hline \multicolumn{5}{|c|}{ Warm regime } \\
\hline 1 & $12(1)$ & $8(2)$ & $6(2)$ & $26(5)$ \\
\hline 2 & $12(1)$ & $8(2)$ & $5(0)$ & $25(3)$ \\
\hline
\end{tabular}

\section{Results}

The study began on July 19, 2016 and all transmitters were inactive in the one monitored tank by September 9, 2016. During this period, there were no antenna failures ( 0 of $51 \mathrm{fish} ; 0 \%)$ in the two cool tanks (table 1-1). However, there were 8 failures (8 of 51; 15.7\%) in the warm tanks (table 1-1); 3 tags failed in tank 2 (on day 11, 19 and 25) and 5 tags failed in tank 1 (on day

4, 8, 8, 15 and 38; fig. 1-3). There was not a significant difference in tag failure rate between the two warm tanks (Wilcoxon test statistic $=0.6452 ; P=0.4218$ ). On September 12, 2016 we used an underwater antenna to determine if transmitters in all of the test tanks had stopped functioning. We found that several transmitters were still active in the cool regime tanks so we turned the water temperature up to test if the elevated temperature would result in additional failures. Warm regime tanks were increased to $18.0{ }^{\circ} \mathrm{C}$ and cool regime tanks were increased to $16.0{ }^{\circ} \mathrm{C}$ (fig. $1-2$ ). We monitored the tanks until September 28, 2016 when the study was terminated. On September 20, 2016 one antenna failed on a transmitter in a warm regime tank, and on September 21, 2016 one antenna failed on a transmitter in a cool regime tank. Overall, during the entire course of the study (July 19-September 28, 2016) we found that antenna failure rates were 17.6\% (9/51) in warm regime tanks and $2.0 \%(1 / 51)$ in cool regime tanks. 


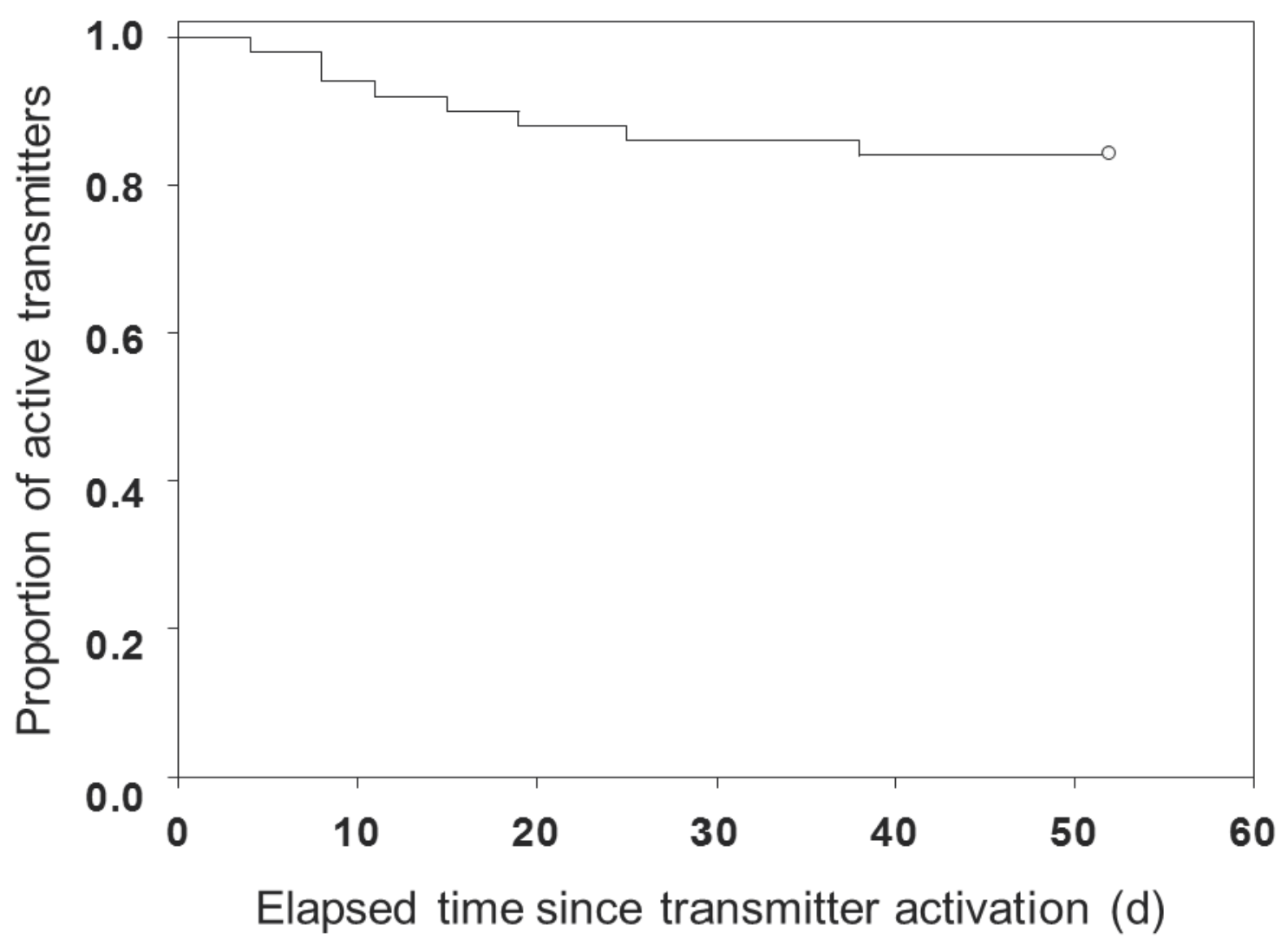

Figure 1-3. Kaplan-Meier survivorship function showing the proportion of transmitter antenna failures that occurred during the study period. All transmitters that did not fail during the study were censored (open circle) at 52 days post-activation which is when battery failure occurred for all transmitters in the study.

\section{Discussion}

The rate of antenna failure observed in the laboratory study was high overall $(10 / 102,9.8 \%)$ and higher in the warm regime $(9 / 51,17.6 \%)$ than the cool regime $(1 / 51,2 \%)$. The cool regime did not have any failures until the water temperature was increased from $12.0{ }^{\circ} \mathrm{C}$ to $16.0^{\circ} \mathrm{C}$, near the end of the evaluation. The single cool regime failure occurred 9 days after the temperature was increased to 16.0 ${ }^{\circ} \mathrm{C}$. After September 12, 2016, when the water temperatures were increased, transmitters were rapidly experiencing battery failure. The single tag that failed in the cool regime experienced battery failure on September 13, 2016, just one day after the temperature had been increased in the tank, and $8 \mathrm{~d}$ before the antenna failed. Antenna failure rates during the test period when tag batteries were known to be functioning were $7.8 \%(8 / 102)$ overall, $15.7 \%(8 / 51)$ in the warm regime, and $0 \%$ in the cool regime. 
The laboratory test reported a higher rate of failure than what was observed in the field studies. For the PGE field study, failure rates were not measurable as fish were not recovered after release, but some failures were noted for fish held prior to release. For the LCPUD field study, a 5.6\% failure rate was noted when fish were recovered at a fish facility following dam passage. We estimate that the observed failure rate in the LCPUD field study was biased low as this type of failure has never previously been reported and therefore staff at the fish facility was likely to have missed identifying fish with failures, especially early in the process of discovering and documenting the issue. Although the field observations were critical to identifying the issue, the reported failure rates cannot reliably be used to make inferences about overall failure rates.

Conditions during the laboratory test effectively simulated field conditions. All transmitters used in the laboratory test were confirmed to be functioning at the start of the test as the operation of the battery and transmitter might influence the antenna failure rate. The tagging protocols used for the laboratory study were the same procedures used by LCPUD and PGE taggers. Furthermore, the chemical solutions, supplies, and materials used for the LCPUD field study were transported to the Columbia River Research Lab and used for the laboratory test in order to replicate field conditions. All field procedures that involved transmitters were followed for the laboratory study, including removal from the shipping container, activation, confirmation of function, and disinfection.

The laboratory study tested the transmitters manufactured for, and used in the LCPUD and PGE field studies so that the results might be used to control for bias in the survival estimates generated by the field studies. In order to have transmitters available for the laboratory tests, some elements of the two field studies were not executed as planned. Now that antenna failure rates have been generated, analytical approaches can be investigated for controlling bias in the survival estimates; however, this adjustment may not be feasible or defensible, and must be pursued independently for each of the two field studies.

\section{References}

Liedtke, T.L., Beeman, J.W., and Gee, L.P., 2012, A standard operating procedure for the surgical implantation of transmitters in juvenile salmonids: U.S. Geological Survey Open-File Report 2012$1267,50 \mathrm{p}$. 
Publishing support provided by the U.S. Geological Survey

Science Publishing Network, Tacoma Publishing Service Center

For more information concerning the research in this report, contact the Director, Western Fisheries Research Center

U.S. Geological Survey

6505 NE 65th Street

Seattle, Washington 98115

https://wfrc.usgs.gov/ 


\section{这}

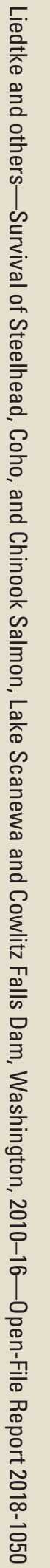

